\title{
Hippocampal-Evoked Feedforward Inhibition in the Nucleus Accumbens
}

\author{
Samantha L. Scudder, Corey Baimel, Emma E. Macdonald, and Adam G. Carter \\ Center for Neural Science, New York University, New York, New York 10003
}

The nucleus accumbens (NAc) is critical for motivated behavior and is rewired following exposure to drugs of abuse. Medium spiny neurons (MSNs) in the NAc express either D1 or D2 receptors and project to distinct downstream targets. Differential activation of these MSNs depends on both excitation from long-range inputs and inhibition via the local circuit. Assessing how long-range excitatory inputs engage inhibitory circuitry is therefore important for understanding NAc function. Here, we use slice electrophysiology and optogenetics to study ventral hippocampal (vHPC)-evoked feedforward inhibition in the NAc of male and female mice. We find that vHPC-evoked excitation is stronger at D1+ than D1- MSNs, whereas inhibition is unbiased at the two cell types. vHPC inputs contact both parvalbumin-positive $(\mathrm{PV}+)$ and somatostatin-positive $(\mathrm{SOM}+)$ interneurons, but $\mathrm{PV}+$ cells are preferentially activated. Moreover, suppressing PV + interneurons indicates they are primarily responsible for vHPC-evoked inhibition. Finally, repeated cocaine exposure alters the excitation of D1 + and D1- MSNs, without concomitant changes to inhibition, shifting the excitation/inhibition balance. Together, our results highlight the contributions of multiple interneuron populations to feedforward inhibition in the NAc. Moreover, they demonstrate that inhibition provides a stable backdrop on which drug-evoked changes to excitation occur within this circuit.

Key words: cocaine; feedforward inhibition; interneuron; medium spiny neuron; nucleus accumbens; synaptic transmission

Significance Statement

Given the importance of the nucleus accumbens (NAc) in reward learning and drug-seeking behaviors, it is critical to understand what controls the activity of cells in this region. While excitatory inputs to projection neurons in the NAc have been identified, it is unclear how the local inhibitory network becomes engaged. Here, we identify a sparse population of interneurons responsible for feedforward inhibition evoked by ventral hippocampal input and characterize their connections within the NAc. We also demonstrate that the balance of excitation and inhibition that projection neurons experience is altered by exposure to cocaine. Together, this work provides insight into the fundamental circuitry of this region as well as the effects of drugs of abuse.

\section{Introduction}

The nucleus accumbens (NAc) plays a key role in reward learning and motivated behavior (Humphries and Prescott, 2010; Sesack and Grace, 2010), and NAc circuits are disrupted by exposure to drugs of abuse (Robinson and Kolb, 2004; Russo et al., 2010). Medium spiny neurons (MSNs) are the principal cells of the NAc (Kreitzer, 2009) and are responsible for inhibiting downstream targets in the basal ganglia (Gerfen and Bolam, 2010). While MSNs respond to excitatory inputs from other brain regions

\footnotetext{
Received Aug. 1, 2018; revised Aug. 24, 2018; accepted Aug. 28, 2018.

Author contributions:S.L.S., C.B., and A.G.C. designed research;S.L.S., C.B., and E.E.M. performed research;S.L.S. and C.B. analyzed data; S.L.S. and A.G.C. wrote the paper.

This work was supported by National Institutes of Health Grants F32 DA044691 (S.L.S.) and R01 DA038138 (A.G.C.), a Canadian Institutes of Health Research postdoctoral fellowship (C.B.), and a New York University Dean's Undergraduate Research Fund award (E.E.M.). The authors have no financial conflicts of interest. We thank members of the Carter lab and Margaret Rice for helpful discussions and comments on this manuscript.

Correspondence should be addressed to Adam G. Carter at the above address. E-mail: adam.carter@nyu.edu. DOI:10.1523/JNEUROSCI.1971-18.2018

Copyright $\odot 2018$ the authors $\quad 0270-6474 / 18 / 389091-14 \$ 15.00 / 0$
}

(O’Donnell and Grace, 1995; Doig et al., 2010), they are also influenced by local inhibition (Tepper et al., 2008; Burke et al., 2017). However, the properties of striatal inhibitory circuits, and how they are impacted by drugs of abuse, remain relatively unexplored.

MSNs are often segregated into two groups, based on the expression of D1 or D2 dopamine receptors (Gerfen et al., 1990; Gerfen and Surmeier, 2011). In the NAc, changes in D1+ and D2 + MSN activity have different consequences for motivated and reward-related behavior (Hikida et al., 2010; Lobo et al., 2010; Bock et al., 2013; Calipari et al., 2016). MSNs rest at very negative membrane potentials and are driven to spike by excitatory inputs from other brain regions, with the ventral hippocampus (vHPC) providing a strong input that preferentially targets the NAc medial shell (Pennartz and Kitai, 1991; O’Donnell and Grace, 1995; Finch, 1996; Britt et al., 2012; MacAskill et al., 2012). Excitatory afferents can segregate between subtypes of MSNs, allowing differential activation of basal ganglia targets (Lei et al., 2004; Wall et al., 2013; Barrientos et al., 
2018). For example, vHPC inputs are strongest onto D1+ MSNs in the NAc medial shell, preferentially triggering these cells to fire action potentials (APs; MacAskill et al., 2012, 2014).

Throughout the brain, excitatory inputs also evoke disynaptic inhibition mediated by local interneurons (Isaacson and Scanziani, 2011). The resulting excitation/inhibition (E/I) ratio governs the activation patterns of neurons and can be altered by experience (Yizhar et al., 2011; Xue et al., 2014; Anastasiades et al., 2018; Moore et al., 2018). In the cortex, inhibition is primarily mediated by local interneurons expressing parvalbumin $(\mathrm{PV}+)$ and somatostatin $(\mathrm{SOM}+)$, which have distinct functional roles (Isaacson and Scanziani, 2011). PV + cells are driven by afferents to mediate feedforward inhibition (Swadlow, 2003), whereas $\mathrm{SOM}+$ cells are thought to be locally activated to mediate feedback inhibition (Silberberg and Markram, 2007), and both populations help to prevent excessive recurrent excitation. However, there are no excitatory cells in the striatum, and no recurrent excitation, suggesting different properties and roles of local inhibition.

As in other parts of the brain, the NAc also contains multiple populations of GABAergic interneurons, including $\mathrm{PV}+$ and SOM+ cells (Kawaguchi, 1993; Kawaguchi et al., 1995; Tepper and Bolam, 2004). In the dorsal striatum, these interneurons inhibit MSNs (Taverna et al., 2007; Gittis et al., 2010; Planert et al., 2010; Straub et al., 2016), with some studies showing preferential targeting of D1+ over D2+ MSNs (Gittis et al., 2010, 2011). Both cortical and thalamic inputs synapse onto PV+ cells in the dorsal striatum to generate feedforward inhibition of MSNs (Rudkin and Sadikot, 1999; Ramanathan et al., 2002; Mallet et al., 2005; Plotkin et al., 2005). While SOM+ cells in the dorsal striatum were shown previously to receive weak cortical input (Choi et al., 2018), little is known about how these interneurons are activated and whether they participate in disynaptic inhibition. Even less is known about afferent connections onto PV+ and SOM+ interneurons in the NAc or their local connections onto different subtypes of MSNs.

Repeated exposure to cocaine and other drugs of abuse dramatically rewires cell-type- and input-specific connectivity in the NAc (Lüscher and Malenka, 2011; Lobo and Nestler, 2011; Smith et al., 2013; Volkow and Morales, 2015). For example, cocaine sensitization normalizes the strength of vHPC inputs, eliminating the baseline bias onto D1+ MSNs (MacAskill et al., 2012). However, any equivalent bias of feedforward inhibition and how it could be influenced by cocaine remain unknown. For example, a cocaine-evoked decrease in vHPC-evoked inhibition at D1+ MSNs could counter the decrease in excitation to balance the $\mathrm{E} / \mathrm{I}$ ratio; in contrast, no effect on inhibition could enable a decrease in the $\mathrm{E} / \mathrm{I}$ ratio, which could lead to differential activation of these cells.

Here, we examine the properties and plasticity of vHPCevoked feedforward inhibition in the NAc medial shell, using a combination of slice physiology and both excitatory and inhibitory optogenetics, taking advantage of a variety of transgenic mice lines. We first determine the E/I balance at $\mathrm{D} 1+$ and $\mathrm{D} 1-$ MSNs, showing that inhibition is equivalent at the two cell types. We then characterize $\mathrm{PV}+$ and $\mathrm{SOM}+$ interneurons in the NAc, examine how they are influenced by vHPC inputs, and explore their output to MSNs. Finally, we assess the impact of cocaine sensitization, showing that it adjusts excitation but not inhibition, changing the E/I ratio. Together, our results provide new insights into inhibitory circuits in the NAc, highlight a critical role for PV + cells in feedforward inhibition, and demonstrate how excitation and inhibition shape the activation of MSNs.

\section{Materials and Methods}

Animals and surgeries. Physiology experiments were performed using D1-tdTomato hemizygous bacterial artificial chromosome (BAC) transgenic mice (Ade et al., 2011) crossed with PV-2A-Cre (Madisen et al., 2010), SOM-Cre (Taniguchi et al., 2011), or wild-type C57BL/6J (wildtype) mice (originally purchased from Jackson Laboratories). Behavior and anatomy experiments also used wild-type, $P V$-Cre (Hippenmeyer et al., 2005), D2-EGFP (Gong et al., 2003), and Ai14 reporter (Madisen et al., 2010) mice. Animals of both sexes were used, and experiments were conducted on postnatal day 29 (P29)-P56 mice, as described below in the Slice physiology section. All procedures were conducted in accordance with guidelines approved by the New York University Animal Welfare Committee.

Stereotaxic injections were performed on P29-P46 mice, as described previously (Little and Carter, 2012; Anastasiades et al., 2018). Injection site coordinates were determined relative to bregma [mediolateral axis, dorsoventral axis, and rostrocaudal axis (in mm): NAc, $-2,-4.6,+1.5$, at a $13^{\circ}$ angle; vHPC, $-3.1,-4.6$ and $-4.2,-3.3$ ]. A total of $183-370 \mathrm{nl}$ of adeno-associated virus (AAV) was injected via a glass pipette and NanoJect III injection system (Drummond), and pipettes were left in place for at least $5 \mathrm{~min}$ after injection. Cre-dependent fluorophores and channelrhodopsin-2 (ChR2) (AAV1-CAG-FLEX-EGFP, AAV1-EF1aDIO-EYFP, and AAV1-EF1a-DIO-ChR2-EYFP; UPenn Vector Core, Philadelphia) were given a minimum of $9 \mathrm{~d}$ to express before conducting experiments, while non-Cre-dependent fluorophores and ChR2 for labeling of long-range inputs (AAV1-CaMKIIa-ChR2-mCherry and AAV1-CB7-CI-mCherry, UPenn Vector Core) were given a minimum of $14 \mathrm{~d}$, and Cre-dependent archaerhodopsin (ArchT) (AAV9-CAG-FLEXArchT-GFP; University of North Carolina Vector Core, Chapel Hill) was given a minimum of $21 \mathrm{~d}$.

Slice physiology. For acute slice preparation, P42-P56 mice were first deeply anesthetized using an intraperitoneal injection of a fatal dose of ketamine and xylazine, before an intracardial perfusion with an ice-cold sucrose cutting solution [containing (in $\mathrm{mm}$ ) 65 sucrose, $75 \mathrm{NaCl}, 25$ $\mathrm{NaHCO}_{3}, 1.25 \mathrm{NaH}_{2} \mathrm{PO}_{4}, 25$ glucose, $2.5 \mathrm{KCl}, 7 \mathrm{MgCl}_{2}, 0.4 \mathrm{Na}-$ ascorbate, and $2 \mathrm{Na}$-pyruvate]. Coronal sections (300 $\mu \mathrm{m}$ thick) of the NAc were sliced on a VS1200 vibratome (Leica) and transferred to $35^{\circ} \mathrm{C}$ ACSF [containing (in mu) $119 \mathrm{NaCl}, 25 \mathrm{NaHCO}_{3}, 1.4 \mathrm{NaH}_{2} \mathrm{PO}_{4}, 25$ glucose, $2.5 \mathrm{KCl}, 2 \mathrm{CaCl}_{2}, 1 \mathrm{MgCl}_{2}, 0.4 \mathrm{Na}$-ascorbate, and $2 \mathrm{Na}$-pyruvate] for a $30 \mathrm{~min}$ recovery. Slices were then held at room temperature for at least $30 \mathrm{~min}$ before recording at an elevated temperature of $30-32^{\circ} \mathrm{C}$.

Whole-cell recordings were made from fluorescently identified MSNs and interneurons in the NAc medial shell, located 300-600 $\mu$ m medial to the anterior commissure. D1+ MSNs were identified based on tdTomato expression, and PV + and SOM + interneurons were identified by EGFP or enhanced yellow fluorescent protein (EYFP) expression. Neurons within a pair $(\mathrm{D} 1+\times \mathrm{D} 1-, \mathrm{D} 1+\times \mathrm{PV}+$, or $\mathrm{D} 1+\times \mathrm{SOM}+)$ were located at the same depth in the slice and within $50 \mu \mathrm{m}$ of each other. Recording order was varied for the two cell types in a given pair, as described previously (MacAskill et al., 2014). Voltage-clamp experiments used 3-5 $\mathrm{M} \Omega$ glass pipettes filled with a Cs-based internal [containing (in mM) 130 Cs-gluconate, 10 HEPES, $10 \mathrm{Na}$-phosphocreatine, 4 $\mathrm{Mg}_{2}$-ATP, 0.4 NaGTP, 10 tetraethylammonium (TEA), 2 QX-314, and 10 EGTA, pH 7.3 with $\mathrm{CsOH}$. Current-clamp recordings were conducted with glass pipettes containing a K-based internal [containing (in mM) $135 \mathrm{~K}$-gluconate, $7 \mathrm{KCl}, 10 \mathrm{HEPES}, 10 \mathrm{Na}$-phosphocreatine, $4 \mathrm{Mg}_{2}$-ATP, $0.3 \mathrm{NaGTP}$, and 0.5 EGTA, pH 7.3, with KOH]. Data were collected using a MultiClamp 700B (Molecular Devices), and signals were sampled at $10 \mathrm{~Hz}$ and filtered at $2 \mathrm{~Hz}$ for voltage-clamp and $10 \mathrm{~Hz}$ for current-clamp recordings. Series resistance was $<25$ $\mathrm{M} \Omega$ and left uncompensated.

Neurons were patched using infrared-differential interference contrast. For voltage-clamp recordings of glutamatergic input, cells were held at $-70 \mathrm{mV}$ to measure AMPAR-mediated currents (in $10 \mu \mathrm{M}$ gabazine to block $\mathrm{GABA}_{\mathrm{A}}$ Rs; see Fig. 4). Disynaptic IPSCs were measured at $+20 \mathrm{mV}$ in the presence of 3-(2-carboxypiperazin-4-yl)propyl-1phosphonic acid (CPP, $10 \mu \mathrm{M})$ to block NMDARs, and IPSCs from interneuron stimulation were recorded at the excitatory reversal potential 
$(+15$ or $+20 \mathrm{mV})$ in CPP and NBQX $(10 \mu \mathrm{M})$ to block all glutamatergic currents. During current-clamp recordings (see Fig. 6), cells were left at their resting membrane potentials during LED stimulation. For quantification of all LED-evoked currents and spikes, responses were averaged from at least 10 trials per LED duration with a $10 \mathrm{~s}$ intertrial interval. Current injections (see Fig. 5) were conducted in CPP, NBQX, CGP, and gabazine to block all synaptic currents, and input resistance $\left(R_{\text {in }}\right)$ was calculated using a $-50 \mathrm{pA}$ current injection. All chemicals were purchased from Tocris Bioscience or Sigma.

Optogenetics. Glutamate release from vHPC fibers and GABA release from interneurons expressing ChR2 were triggered using 1-4 ms pulses of $473 \mathrm{~nm}$ light emitted from an LED through a $60 \times$ objective for evaluation of direct excitation or inhibition (see Figs. 3, 4, 6) and through a $10 \times$ objective for disynaptic inhibition (see Figs. 1, 7, 8), with intensity set to $0.5-4 \mathrm{~mW}$ at the back aperture of the objective. Within a pair of neurons, an intensity was chosen that yielded usable responses (i.e., 501200 pA EPSC amplitude for voltage-clamp experiments). For optogenetic suppression experiments (see Fig. 7), blue and yellow light was presented through the $10 \times$ objective. In these experiments, yellow light $(590 \mathrm{~nm}, 3.5 \mathrm{~mW})$ was delivered at $50 \mathrm{~ms}$ before a $2 \mathrm{~ms}$ blue LED pulse and persisted for $350 \mathrm{~ms}$ in total (see Fig. 7A). Following prolonged suppression by yellow light, ArchT causes rebound GABA release at ArchT + terminals, which is detected in the postsynaptic cell (D1+ MSN) as a barrage of IPSCs upon termination of yellow illumination (Mahn et al., 2016). We used the presence of these rebound IPSCs to evaluate successful viral infection and suppression of PV + cells, and for our analysis we included only data where this effect was observed. Additionally, slices were evaluated using fluorescence microscopy to determine sufficient infection of the PV+ population.

Two-photon microscopy. To obtain images of patched neurons, cells were filled via patch pipette during whole-cell recording with AlexaFluor-594 dye (30 $\mu \mathrm{M}$ in internal solution) for at least $15 \mathrm{~min}$. Imaging was performed on a custom microscope using a titaniumsapphire laser (Coherent) tuned to $810 \mathrm{~nm}$, as described previously (Carter and Sabatini, 2004; Chalifoux and Carter, 2010). A $z$-stack was acquired at $512 \times 512$ resolution, and images were processed using NIH ImageJ.

Histology and fluorescence microscopy. Mice were deeply anesthetized with a fatal dose of ketamine and xylazine and perfused intracardially with $0.01 \mathrm{M}$ PBS followed by $4 \%$ paraformaldehyde (PFA). Brains were extracted and stored in $4 \%$ PFA for $12-18 \mathrm{~h}$ at $4^{\circ} \mathrm{C}$. Tissue was sliced into $40 \mu \mathrm{m}$ (for immunostaining) or $70 \mu \mathrm{m}$ sections and either mounted directly onto gel-coated glass slides or processed for immunolabeling. After $1 \mathrm{~h}$ incubation with blocking solution (1\% bovine serum albumin and $0.2 \%$ Triton-X in $0.01 \mathrm{M}$ PBS), primary antibodies were applied overnight [mouse anti-parvalbumin antibody (Millipore) at 1:2000, rat anti-somatostatin (Millipore) at 1:200, chicken anti-GFP (Abcam) at 1:1000, or rabbit anti-RFP (Rockland) at 1:1000 in blocking solution]. Slices were incubated with secondary antibodies [goat anti-mouse 647 at 1:200, goat anti-rat 647 at 1:200, goat anti-chicken 488 at 1:500, or goat anti-rabbit 594 at 1:400 (Invitrogen), in blocking solution] for $1.5 \mathrm{~h}$. For $\mathrm{D} 1+/ \mathrm{D} 2+$ quantification, an additional incubation with Alexa-647conjugated rabbit anti-NeuN (Abcam) was conducted, at 1:50 in blocking solution for $2 \mathrm{~h}$. Slices were mounted onto gel-coated glass slides and coverslipped using ProLong Gold with DAPI (Invitrogen) or Vectashield Antifade Mounting Medium (Vector Laboratories). Fluorescence imaging was conducted on an Olympus VS120 slide-scanning microscope or a Leica confocal using a $10 \times$ objective, and all image processing was performed using NIH ImageJ.

Behavior. Adult mice (5-8 weeks of age) of both sexes were first habituated to the behavior room for one $2 \mathrm{~h}$ session. The next day, they were placed in a dimly lit, sound-attenuated behavioral chamber $(1 \times 1$ foot $)$ for one $40 \mathrm{~min}$ habituation session. Behavior was recorded via an overhead camera linked to Ethovision software (Noldus), which quantified locomotor activity during each session. On the following day, mice were placed in the chamber for a $15 \mathrm{~min}$ baseline period followed by intraperitoneal injection of saline and a 20 min postinjection session in the chamber, to acclimate the animals to injections and obtain a baseline locomotion measure. Animals then underwent $5 \mathrm{~d}$ ( 1 session per day) of cocaine $(15 \mathrm{mg} / \mathrm{kg})$ or saline injection sessions in the chamber. Subsequently, animals either underwent a test session, where both cocaine-treated and saline-treated mice received a $15 \mathrm{mg} / \mathrm{kg}$ cocaine intraperitoneal injection, or were anesthetized and perfused for preparation of acute slices, as described previously (MacAskill et al., 2014). Locomotor sensitization data presented were acquired from pairs of animals used only for behavior and represent movement (centimeters per second) during the $20 \mathrm{~min}$ postinjection session. For electrophysiology experiments, D1-tdTomato mice were injected with optogenetic constructs and given at least $3 \mathrm{~d}$ to recover before initiating behavioral sessions, as described above.

Experimental design and statistical analysis. Electrophysiology and two-photon imaging data were acquired using custom software written in MATLAB (MathWorks). All electrophysiology, anatomical, and behavioral data was collected from a minimum of three animals from different litters. Physiology data analysis was performed in Igor Pro (Wavemetrics). EPSC and IPSC amplitudes were averaged from a $1 \mathrm{~ms}$ window around the peak current, and average traces in figures depict means \pm SEM of all recorded pairs. AP probabilities (see Fig. 6) were calculated for $\mathrm{D} 1+$ and $\mathrm{PV}+$ cells as the presence of spikes across a minimum of 10 trials at varying LED intensities. For SOM+ cells, baseline firing rate was calculated from a $500 \mathrm{~ms}$ window with no stimulation, and this value was used to compute a likelihood of observing a spike in the $10 \mathrm{~ms}$ window after stimulation. For each LED intensity in each cell, expected probability was subtracted from observed probability, and the resulting value was plotted and used for statistical comparisons. Statistical significance of differences between two groups was evaluated using the Wilcoxon signed-rank test for paired data or the Mann-Whitney test for unpaired data, with $p$ values of $<0.05$ considered significant. For comparison of AP firing probability across multiple LED durations, a repeated-measures two-way ANOVA was used, with Sidak's post hoc multiple comparisons test. Significance of the LED duration by cell-type interaction is reported. Image analysis was conducted using NIH ImageJ. Statistical tests and graph generation were performed using Prism (GraphPad).

\section{Results}

vHPC inputs drive robust feedforward inhibition in the NAc We examined how vHPC afferents engage local inhibitory circuits mediated by GABAergic interneurons in the NAc. To examine vHPC inputs, we first injected AAV-mCherry in the vHPC (Fig. 1A) and observed prominent axons in the NAc medial shell (Fig. 1B; $n=3$ mice; Britt et al., 2012; MacAskill et al., 2012, 2014). To assess connectivity, it was important to identify D1+ MSNs, which have been reported to overlap with D2+ MSNs in the ventral striatum (Wong et al., 1999). However, when we crossed D1-tdTomato with D2-EGFP mice, we observed minimal overlap between $\mathrm{D} 1+$ and D2 + MSNs in the NAc medial shell (Fig. $1 C ; n=$ 3 slices, 2 mice). These results indicate that most D1- MSNs are D2 + MSNs, allowing us to compare synaptic responses at D1+ and D1 - MSNs using D1-tdTomato mice (Ade et al., 2011).

To study synaptic responses, we next injected AAV-CaMKIIChR2-mCherry into the vHPC, giving us optogenetic access to glutamatergic projections from this region. We then made sequential voltage-clamp recordings from neighboring $\mathrm{D} 1+$ and D1 - MSNs within the NAc medial shell in acute slices and confirmed their identity as MSNs morphologically via two-photon imaging (Fig. 1D). We found that wide-field illumination of vHPC inputs evoked short latency EPSCs at $-70 \mathrm{mV}$ in both cell types (Fig. $1 E$ ), but excitatory responses were much larger in D1+ MSNs (Fig. 1F; EPSC amplitude: D1 $=400 \pm 48$ pA; $\mathrm{D} 1-=198 \pm 40 \mathrm{pA} ; p<0.001 ; n=13$ pairs, 12 mice). $\mathrm{vHPC}$ stimulation also evoked delayed IPSCs at $+20 \mathrm{mV}$ (Fig. 1E), which were eliminated by the AMPA receptor antagonist NBQX $(10 \mu \mathrm{M}$; percentage of baseline: $\mathrm{D} 1+=1.5 \pm 0.5 ; \mathrm{D} 1-=0.3 \pm$ $0.5 ; n=3,4$ cells), indicating they reflect robust feedforward 
A

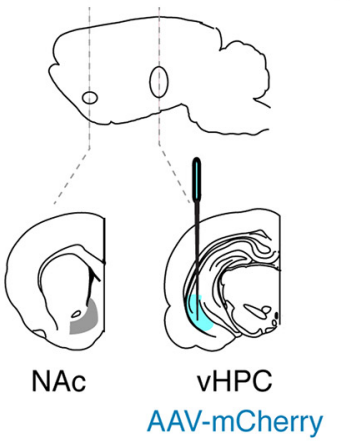

C

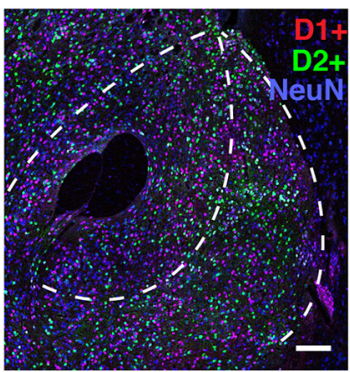

E

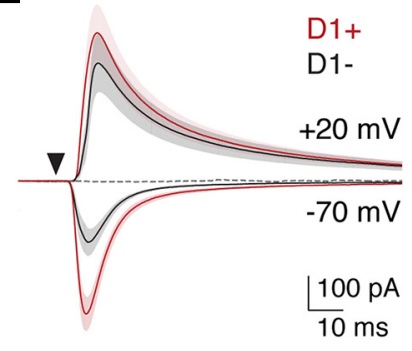

B
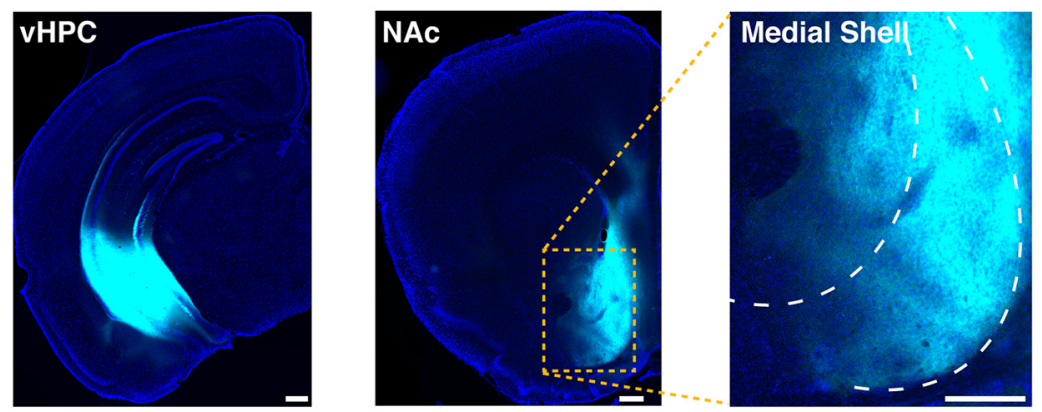

D
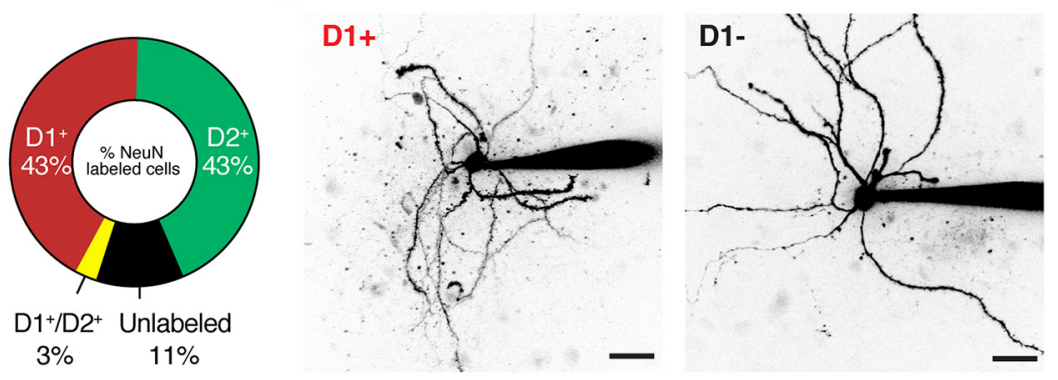

F
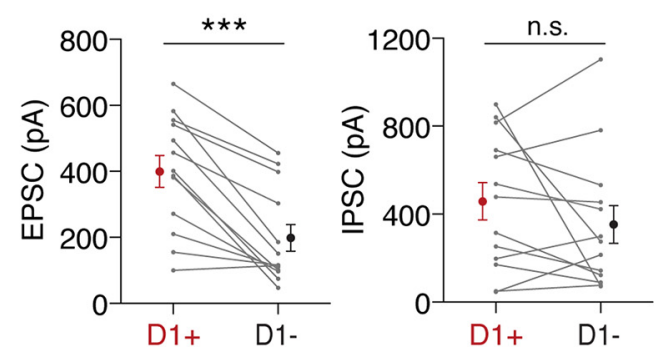

G

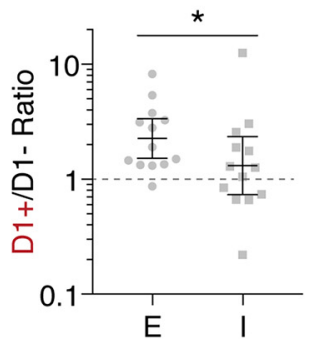

Figure 1. Ventral hippocampal input evokes disynaptic inhibition in the NAc. $A$, Schematic of AAV-mCherry injection into the vHPC to label projections to the NAc. $\boldsymbol{B}$, Example of injection site in the vHPC (left) and fluorescent fibers in the NAc medial shell (middle), with an expanded view (right). C, Left, Confocal image showing distribution of fluorescent cells in the NAc of a D1-tdTomato $X$ D2-EGFP mouse, with NeuN staining (blue) to identify neurons, and anti-GFP (green) and anti-RFP (red) antibodies to enhance fluorescent signals. Right, Quantification of D1 + and D2 + cells relative to total NeuN-labeled cells. D, Example two-photon images of D1 + and D1 - MSNs filled with Alexa-594 via the patch pipette. E, Average vHPC-evoked EPSCs at $-70 \mathrm{mV}$ and IPSCs at +20 $\mathrm{mV}$ in D1 + (red) and D1 - (black) MSNs, in the presence of the NMDAR antagonist CPP. The triangle indicates a light pulse. Addition of the AMPAR antagonist NBQX eliminates the IPSCS (dotted line), indicating a disynaptic response. $\boldsymbol{F}$, Summary of EPSC amplitudes (left) and IPSC amplitudes (right) in D1 + and D1 - MSNs, where connected data points indicate pairs of neurons. Data are presented as arithmetic means \pm SEM. G, Ratio of D1 + to D1 - current amplitudes for EPSCs and IPSCs. Data are presented as geometric means with 95\% confidence intervals. Note the logarithmic axis. Scale bars: $\boldsymbol{B}, 300 \mu \mathrm{m} ; \boldsymbol{C}, 100 \mu \mathrm{m} ; \boldsymbol{D}, 20 \mu \mathrm{m}$. n.s., Not significant $(p>0.05) .{ }^{*} p<0.05 ;{ }^{* * *} p<0.001$.

inhibition. In contrast to excitation, these inhibitory responses did not differ significantly between D1+ and D1- MSNs (Fig. $1 F$; IPSC amplitude: $\mathrm{D} 1+=458 \pm 85 \mathrm{pA} ; \mathrm{D} 1-=353 \pm 86 \mathrm{pA}$; $p=0.41 ; n=13$ pairs, 12 mice). Consequently, the resulting $\mathrm{D} 1+/ \mathrm{D} 1-$ ratios were distinct for $\mathrm{E}$ and $\mathrm{I}[\mathrm{Fig} .1 G$; $\mathrm{D} 1+/ \mathrm{D} 1-$ ratio: EPSC $=2.3,95 \%$ confidence interval $(\mathrm{CI}): 1.5-3.4$; IPSC $=1.3$, CI: $0.7-2.4 ; p=0.03 ; n=13$ pairs, 12 mice], with biased excitation onto D1+ MSNs but unbiased inhibition at the two cell types.

\section{$\mathrm{PV}+$ and SOM+ interneurons are distinct populations in the NAc}

To determine the source of vHPC-evoked feedforward inhibition, we next examined GABAergic interneurons in the NAc medial shell. While most cells are D1+ or D2+ MSNs (Gerfen and Surmeier, 2011), cells expressing parvalbumin (PV+) or somatostatin $(\mathrm{SOM}+)$ are also present (Tepper and Bolam, 2004) and could mediate disynaptic inhibition (Fig. 2A). We first examined
$\mathrm{PV}+$ cells by crossing PV-Cre (Pvalb $\left.{ }^{t m 1(c r e) A r b r}\right)$ mice with Credependent tdTomato reporter (Ai14) mice. Surprisingly, we observed tdTomato + cells throughout cortical regions, but found little expression in the striatum, including the NAc medial shell. Injection of a Cre-dependent reporter virus (AAV-FLEX-EGFP) also failed to reveal cells in the NAc medial shell (Fig. $2 B ; n=3$ mice). Next, we tested $P V-2 A-C r e$ (Pvalb-2A-Cre-D) mice with injection of AAV-FLEX-EGFP and observed numerous EGFP+ neurons throughout the NAc medial shell, which stained positive for PV but not SOM (Fig. $2 C$; PV $+=87.8 \pm 1.3 \%$; $\mathrm{SOM}+=$ $1.6 \pm 0.8 \% ; n=6$ slices, 3 mice). These PV + cells were distinct from D1+ MSNs, as EGFP+ cells were D1 negative in crossed $P V-2 A$-Cre $\times$ D1-tdTomato mice (Fig. $2 C$; D1 $+=1.5 \pm 0.7 \%$; $n=6$ slices, 3 mice). These results highlight the importance of using appropriate transgenic lines for studying PV + interneurons in ventral striatum. 
A

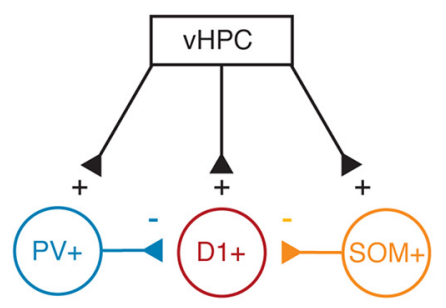

B

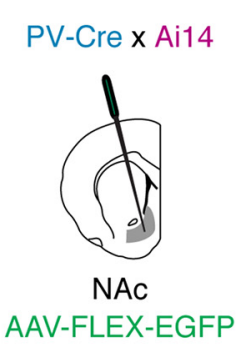

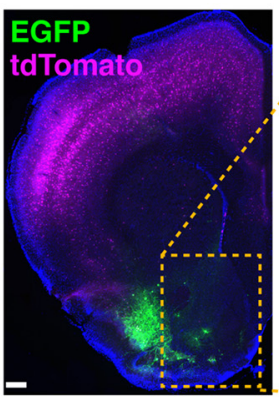

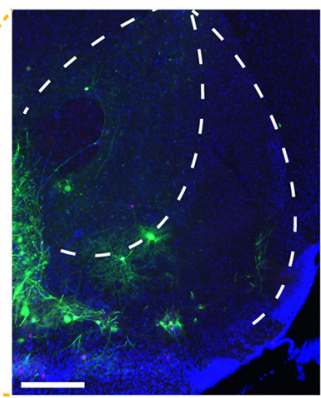

\section{C}

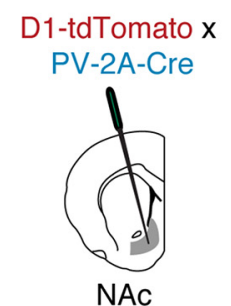

AAV-FLEX-EGFP
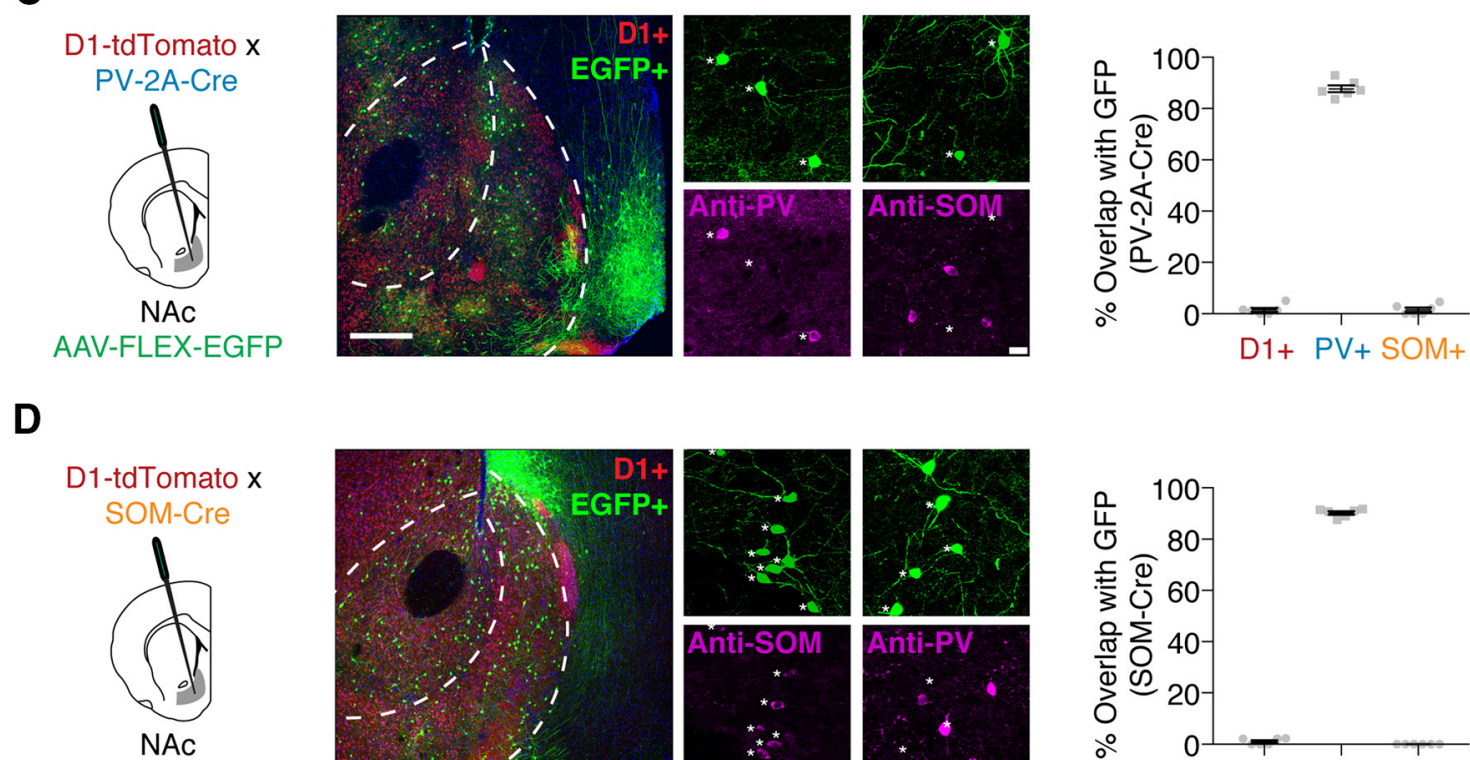

AAV-FLEX-EGFP
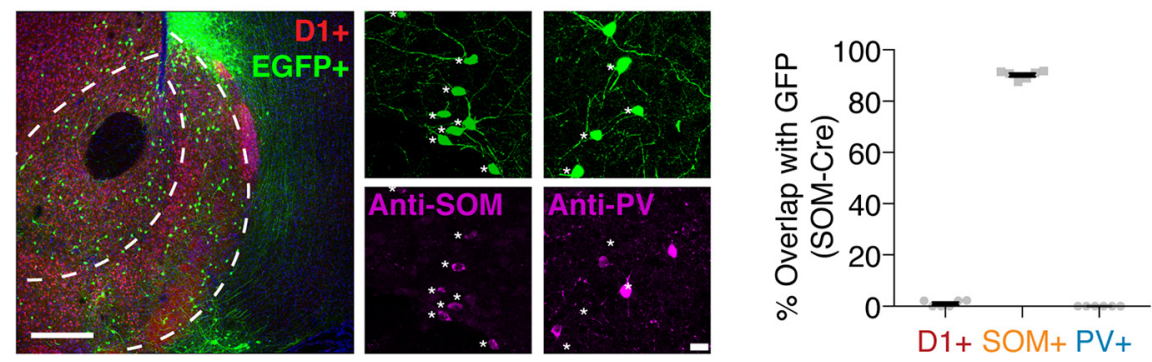

Figure 2. Distinct populations of GABAergic interneurons in the NAc. $A$, Schematic of potential feedforward inhibitory circuitry in the NAc, with PV + and/or SOM + neurons receiving vHPC inputs and inhibiting D1+ MSNs to evoke disynaptic inhibition. $\boldsymbol{B}$, Injection of AAV-FLEX-EGFP into the NAc of PV-Cre $\times$ Ai14 tdTomato reporter mice, with coronal slices of the NAc showing lack of Cre-dependent cell labeling. C, Injection of AAV-FLEX-EGFP into the NAc of PV-2A-Cre $\times$ D1-tdTomato mice to label PV + neurons. EGFP + cells stain positively for antibodies against PV but not SOM, and show little overlap with D1 + MSNs. D, Similar for injection of AAV-FLEX-EGFP into NAc of SOM-Cre $\times$ D1-tdTomato mice to label SOM + neurons. EGFP + cells stain positively for antibodies against SOM but not PV, and show little overlap with D1 + MSNs. For $\boldsymbol{C}$ and $\boldsymbol{D}$, quantification is mean \pm SEM for six slices from three animals per condition. Scale bars: $\boldsymbol{B}, 300 \mu \mathrm{m} ; \boldsymbol{C}, \boldsymbol{D}$, left, $300 \mu \mathrm{m}$; right, $20 \mu \mathrm{m}$.

To identify SOM+ interneurons, we injected AAV-FLEXEGFP into SOM-Cre (Sst-IRES-Cre) mice, labeling EGFP+ cells throughout the NAc medial shell, which stained positive for SOM but not PV (Fig. $2 D$; SOM $+=90.2 \pm 0.7 \%$; PV $+=0.0 \pm 0.0 \%$; $n=6$ slices, 3 mice). Again, these $\mathrm{SOM}+$ cells showed negligible overlap with D1+ MSNs, indicating that they represent a unique population (Fig. $2 D ; \mathrm{D} 1+=1.1 \pm 0.5 \% ; n=6$ slices, 3 mice). Together, these anatomical approaches demonstrate that $\mathrm{D} 1+$, $\mathrm{PV}+$, and $\mathrm{SOM}+$ cells represent three distinct cell types within the NAc medial shell, which can be accurately accessed with viral tools in these transgenic lines.

\section{$\mathrm{PV}+$ and SOM+ interneurons equally inhibit $\mathrm{D} 1+$ and D1- MSNs}

To mediate feedforward inhibition, GABAergic interneurons must make direct inhibitory connections onto local neurons. Previous studies in the dorsal striatum demonstrated that PV+ interneurons can contact both D1+ and D2+ MSNs (Gittis et al., 2010; Planert et al., 2010). We explored whether PV+ and $\mathrm{SOM}+$ cells in the NAc inhibit MSNs, and whether their targeting depends on MSN subtype. We injected Cre-dependent ChR2
(AAV-DIO-ChR2-EYFP) into the NAc of either PV-2A-Cre $\times$ $D 1$-tdTomato or SOM-Cre $\times D 1$-tdTomato mice. This allowed us to drive time-locked action potential firing of $\mathrm{PV}+$ or $\mathrm{SOM}+$ cells in current-clamp recordings from resting potentials $\left(V_{\text {rest }}\right.$; Fig. $3 A, C)$. We next recorded IPSCs from pairs of D1+ and D1MSNs in the same slice, in the presence of glutamate receptor antagonists. We found that stimulation of $\mathrm{PV}+$ interneurons evoked similar amplitude IPSCs in nearby D1 + and D1- MSNs (Fig. 3B; IPSC amplitude: D1 $+=359 \pm 75$ pA; D1 $-=298 \pm 55$ $\mathrm{pA} ; p=0.69 ; n=7$ pairs, 4 mice). Stimulation of SOM+ interneurons also resulted in equivalent inhibition at the two classes of MSNs (Fig. 3D; IPSC amplitude: D1 $=207 \pm 41 \mathrm{pA}$; $\mathrm{D} 1-=165 \pm 34 \mathrm{pA} ; p=0.46 ; n=8$ pairs, 5 mice). Together, these data demonstrate that both populations of interneurons provide direct GABAergic input to MSNs, with no evidence of biased targeting.

\section{vHPC afferents preferentially target $\mathrm{PV}+$ interneurons}

Having confirmed the presence of $\mathrm{PV}+$ and $\mathrm{SOM}+$ interneurons in the NAc medial shell and their ability to inhibit MSNs, we next assessed whether they receive vHPC input. We labeled PV + and 
A

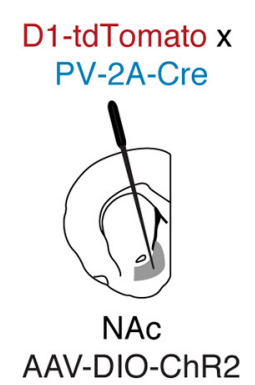

C

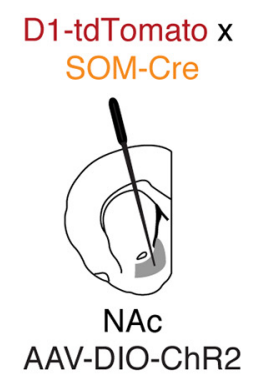

B

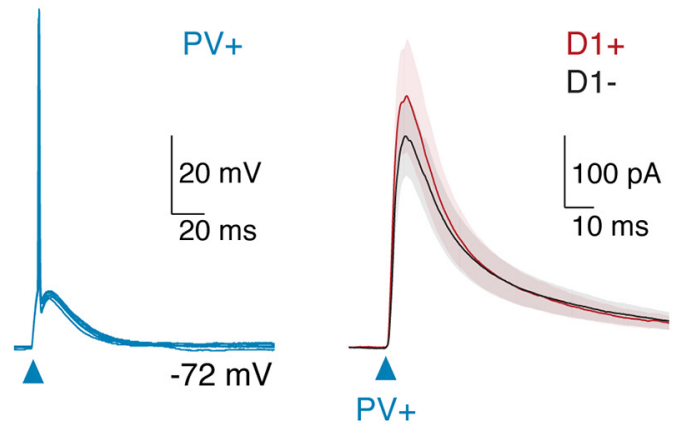

D
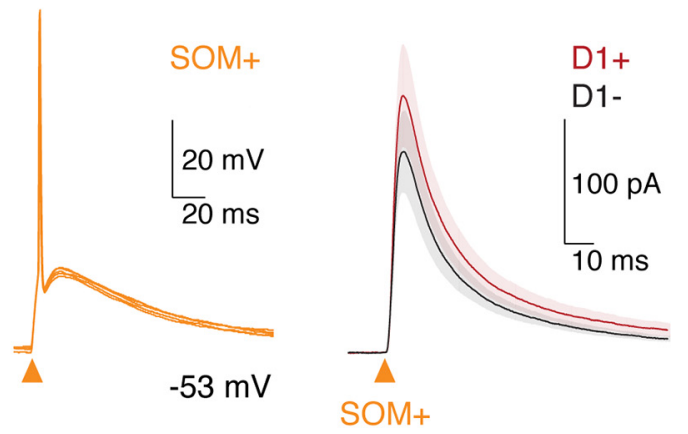
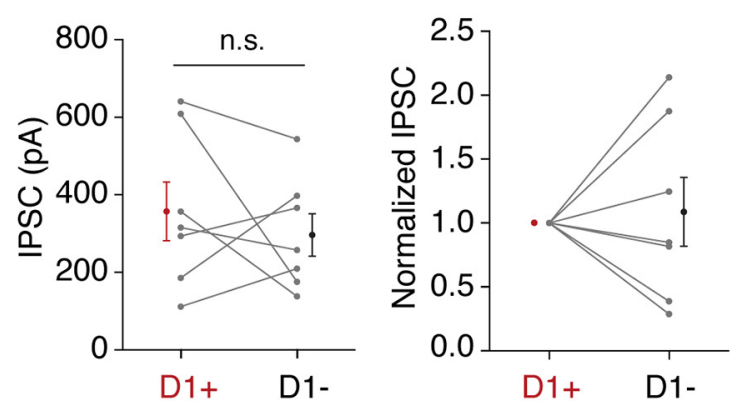

Figure 3. $P V+$ and SOM + interneurons inhibit D1 + and D1 - MSNs in the NAC. A, Left, Schematic of AAV-DI0-ChR2 injection into the NAC of PV-2A-Cre $\times$ D1-tdTomato mice to allow for optogenetic activation of PV + interneurons. Right, Current-clamp recording of light-evoked firing of a ChR2 + PV + cell from resting membrane potential, showing five overlapping traces. $B$, Left, Average PV + -evoked IPSCs at pairs of D1 + and D1 - MSNs held at $+20 \mathrm{mV}$ in the presence of AMPAR antagonist NBQX and NMDAR antagonist CPP. Middle, IPSC amplitudes in D1+ and D1 MSNs, shown as means \pm SEM with pairs linked by lines. Right, Responses normalized to the D1+ MSN. C, D, Same as in $\boldsymbol{A}$ and $\boldsymbol{B}$, but using SOM-Cre $\times$ D1-tdTomato mice to stimulate SOM + interneurons. n.s., Not significant.

$\mathrm{SOM}+$ cells using AAV-DIO-EYFP in either PV-2A-Cre $\times$ D1tdTomato or SOM-Cre $\times$ D1-tdTomato mice. We also injected AAV-CaMKII-ChR2-mCherry into the vHPC, allowed several weeks for expression, and made sequential recordings from neighboring D1 + MSNs and either PV + or SOM+ interneurons in the same slice (Fig. 4A,D). Comparing D1+ and PV + cells, we observed short-latency EPSCs at $-70 \mathrm{mV}$, with much larger inputs at PV+ interneurons (Fig. $4 B, C$; EPSC amplitude: D1+ = $184 \pm 55 \mathrm{pA} ; \mathrm{PV}+=736 \pm 110 \mathrm{pA} ; p=0.008 ; n=8$ pairs, 5 mice). However, comparing D1 + and SOM + cells, we observed the opposite relationship, with much smaller inputs at SOM+ interneurons (Fig. 4E, F; EPSC amplitude: D1 $+=699 \pm 132 \mathrm{pA}$; $\mathrm{SOM}+=100 \pm 23 \mathrm{pA} ; p=0.008 ; n=8$ pairs, 6 mice). These results indicate that although vHPC afferents contact multiple cell types in the NAc medial shell, they exhibit marked preference, with $\mathrm{PV}+$ cells receiving the strongest input, $\mathrm{SOM}+$ cells the weakest, and D1+ MSNs intermediate.

\section{MSNs and interneurons have distinct intrinsic properties}

While these voltage-clamp experiments indicate a targeting bias, the intrinsic properties of neurons also shape synaptic responses. We next examined the intrinsic properties of $\mathrm{D} 1+, \mathrm{D} 1-, \mathrm{PV}+$, and $\mathrm{SOM}+$ cells in current-clamp recordings (Fig. 5A). In response to a range of current injections, D1+ and D1- MSNs displayed similar firing properties, input resistances and resting potentials (Fig. $5 B, C$; $R_{\mathrm{in}}$ : D1+ $=216 \pm 47 \mathrm{M} \Omega$; D1- $=190 \pm$ $36 \mathrm{M} \Omega$; $V_{\text {rest }}: \mathrm{D} 1+=-82 \pm 1 \mathrm{mV} ; \mathrm{D} 1-=-80 \mathrm{mV} \pm 2 \mathrm{mV}$; $n=6$ cells each), as reported previously in the dorsal striatum (Cepeda et al., 2008; Gertler et al., 2008). In contrast, PV+ and $\mathrm{SOM}+$ interneurons exhibited lower and higher input resis- tances than MSNs, respectively (Fig. $5 B, C ; R_{\mathrm{in}}: \mathrm{PV}+=94 \pm 11$ $\mathrm{M} \Omega ; \mathrm{SOM}+=830 \pm 85 \mathrm{M} \Omega ; n=7$ cells each), indicating that $\mathrm{SOM}+$ cells are much more excitable. Interestingly, most SOM+ cells also exhibited spontaneous activity, as seen in the dorsal striatum (Beatty et al., 2012), with the remainder resting near threshold potential, and substantially more depolarized than either MSNs or $\mathrm{PV}+$ interneurons (Fig. $5 \mathrm{~B}, \mathrm{C}$; $V_{\text {rest }}$ : $\mathrm{PV}+=$ $-75 \pm 1 \mathrm{mV}$; SOM $+=-50 \pm 2 \mathrm{mV})$. These data suggest that $\mathrm{SOM}+$ cells are highly excitable neurons, which may not require strong input to influence spiking. Indeed, during current injections from rest, $\mathrm{SOM}+$ cells reach their maximum firing rate with only $40 \mathrm{pA}$, while MSNs require a minimum of $100 \mathrm{pA}$ to generate APs. In contrast, $\mathrm{PV}+$ cells require a $200 \mathrm{pA}$ current injection to fire APs, but are able to reach much higher firing rates with large current injections, typical of fast-spiking interneurons in circuits located throughout the brain (Fig. 5B; Kawaguchi, 1993; Hu et al., 2014).

\section{vHPC inputs most strongly activate $\mathrm{PV}+$ interneurons}

Given that $\mathrm{D} 1+, \mathrm{PV}+$, and SOM + cells have highly divergent excitability, we next sought to determine the impact of vHPC input on AP firing. We again used a dual virus strategy, expressing ChR2 in vHPC afferent fibers, and labeling PV+ or SOM+ interneurons alongside tdTomato $+(\mathrm{D} 1+) \mathrm{MSN}$ in the NAc. We recorded sequential pairs of nearby $\mathrm{D} 1+\times \mathrm{PV}+$ or $\mathrm{D} 1+\times$ $\mathrm{SOM}+$ cells in current-clamp mode at resting membrane potentials, in conditions that isolated excitatory responses. We found that vHPC inputs evoked APs in most D1+ and PV + cells (Fig. $6 A$ ), but PV + interneurons displayed a higher probability of spiking with the same light stimulation (Fig. 6B; two-way 
A

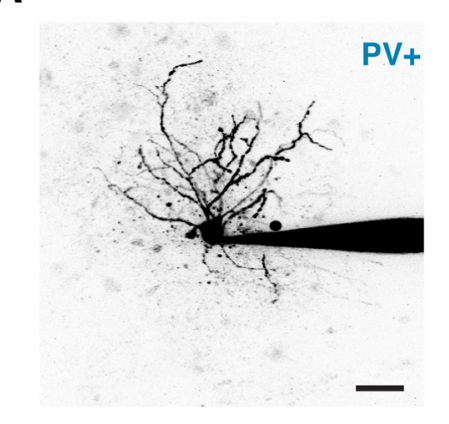

D

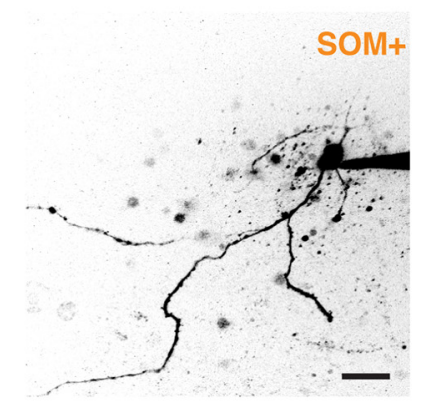

B

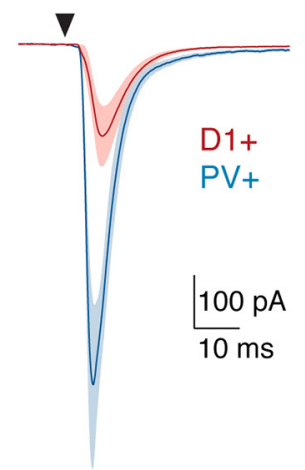

E

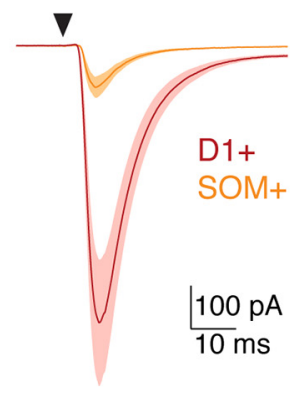

C
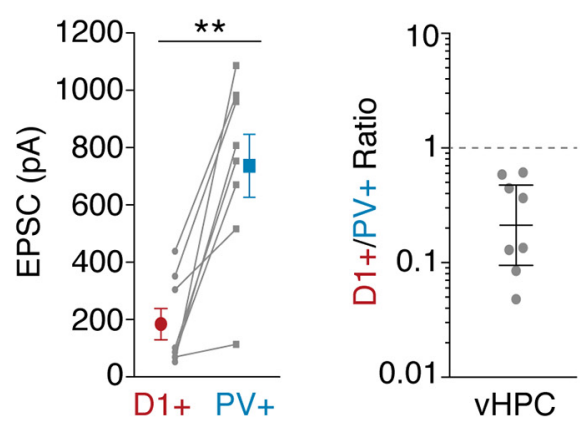

F

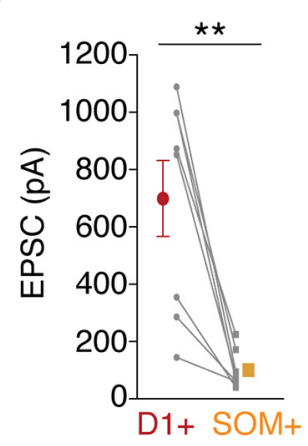

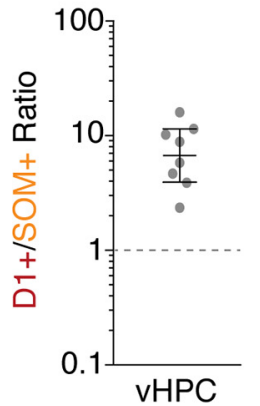

Figure 4. Ventral hippocampal afferents preferentially contact PV + interneurons. $\boldsymbol{A}$, Two-photon image of a PV + interneuron (identified by $C$ re-dependent EGFP + expression in a PV-2A(re $\times$ D1-tdTomato mouse) filled with Alexa-594 via the patch pipette. $B$, Average vHPC-evoked EPSCs recorded at $-70 \mathrm{mV}$ in pairs of D1+ and PV + cells in the NAc medial shell. The triangle indicates a light pulse. $C$, Left, Quantification of EPSC amplitude in D1+ and PV + neurons, indicating stronger vHPC inputs to PV+ cells, shown as means \pm SEM, with lines connecting recorded pairs. Right, Ratios of D1+ to PV+ EPSC amplitudes, shown as geometric means with $95 \%$ confidence intervals. Note the logarithmic axis. $\boldsymbol{D}-\boldsymbol{F}$, Same as for $\boldsymbol{A}-\boldsymbol{C}$ for D1+ versus S0M+ comparisons, illustrating stronger targeting of D1+ neurons by vHPC inputs. Scale bars, $20 \mu \mathrm{m} .{ }^{* *} p<0.01$.

ANOVA, duration $\times$ cell type interaction: $F_{(3,24)}=7.94, p=$ $0.0008 ; n=7$ pairs, 5 mice). Additionally, in cells that fired, vHPC-evoked AP firing of PV+ interneurons occurred faster than at D1+ MSNs (Fig. $6 C$; latency to spike: $\mathrm{D} 1+=8.1 \pm 0.3$ $\mathrm{ms} ; \mathrm{PV}+=5.6 \pm 0.3 \mathrm{~ms} ; p=0.003 ; n=5$ and 7 cells, respectively, from 5 mice). These findings indicate that PV + cells are more readily triggered to fire APs than MSNs, suggesting they may mediate feedforward inhibition.

The majority of SOM + interneurons in the NAc exhibited spontaneous activity, generating a background rate of firing (Fig. $6 D)$. We quantified the influence of vHPC input as the spike probability in a $10 \mathrm{~ms}$ window after stimulation minus the baseline firing probability, focusing on a time window for spiking that would enable generation of the disynaptic IPSCs we observed in MSNs (Fig. $1 E$; onset of IPSC: D1+ $=7.7 \pm 0.4 \mathrm{~ms}$; range $=$ 6.1-10.5 ms). When glutamatergic input was pharmacologically isolated using the $\mathrm{GABA}_{\mathrm{A}}$ receptor antagonist gabazine (+GZ), vHPC inputs evoked spiking across a range of light durations, with nearby D1+ MSNs similarly driven to spike (Fig. 6E,F; two-way ANOVA, duration $\times$ cell type interaction: $F_{(3,32)}=0.29$, $p=0.83 ; n=9$ pairs, 6 mice). When we expanded our detection window to include spikes within $50 \mathrm{~ms}$ of stimulation, we observed vHPC-evoked APs in SOM+ interneurons with much slower latency than those of D1+ MSNs (Fig. 6G; latency to spike: $\mathrm{D} 1+=7.4 \pm 0.7 \mathrm{~ms} ; \mathrm{SOM}+=14.3 \pm 2.0 \mathrm{~ms} ; p=0.006 ; n=8$ and 9 cells, respectively, from 6 mice). While vHPC input was capable of inducing spikes with a longer latency, spikes that occur outside of the initial $10 \mathrm{~ms}$ window would be unable to contribute to the feedforward inhibition that we have observed in D1 + cells.
We hypothesized that the slow response in SOM+ cells could also leave them more vulnerable to feedforward inhibition generated by other cells, potentially disrupting vHPC-evoked excitation. When the $\mathrm{GABA}_{\mathrm{A}}$ receptor blocker gabazine was omitted to keep local inhibition intact $(-\mathrm{GZ})$, vHPC had an even weaker influence over SOM + firing, with many trials failing to evoke a single spike even at high stimulation durations (Fig. 6H-J; twoway ANOVA, duration $\times$ cell type interaction: $F_{(3,32)}=4.55, p=$ $0.009 ; n=9$ pairs, 5 mice). Interestingly, the baseline firing rate of $\mathrm{SOM}+$ cells was also much lower with inhibition intact, suggesting this population is under tonic suppression (Fig. $6 \mathrm{~K}$; firing rate: without gabazine $=3.4 \pm 0.3 \mathrm{~Hz}$; with gabazine $=7.4 \pm 0.7$ $\mathrm{Hz} ; p<0.001 ; n=9$ cells, 5 or 6 mice each). Together, these data suggest $\mathrm{SOM}+$ neurons in the NAc are more likely the recipients of vHPC-evoked feedforward inhibition rather than the mediators.

\section{PV + interneurons mediate feedforward inhibition of MSNs}

Given their strong targeting by vHPC inputs, rapid generation of APs, and ability to directly inhibit MSNs, we predicted that PV+ interneurons are the dominant mediator of feedforward inhibition in the NAc. To test this idea, we next combined optogenetic activation of excitatory inputs with inhibition of PV + interneurons, injecting AAV-ChR2 in the VHPC and AAV-FLEX-ArchT in the NAc of $P V$-2A-Cre $\times$ D1-tdTomato mice (Fig. $7 A$ ). In current-clamp recordings from ArchT $+\mathrm{PV}+$ cells, we found that illumination with blue light alone activated vHPC inputs and evoked reliable firing (Fig. $7 B$ ). When applied together, blue and yellow light hyperpolarized PV + and blocked vHPC-evoked fir- 
A
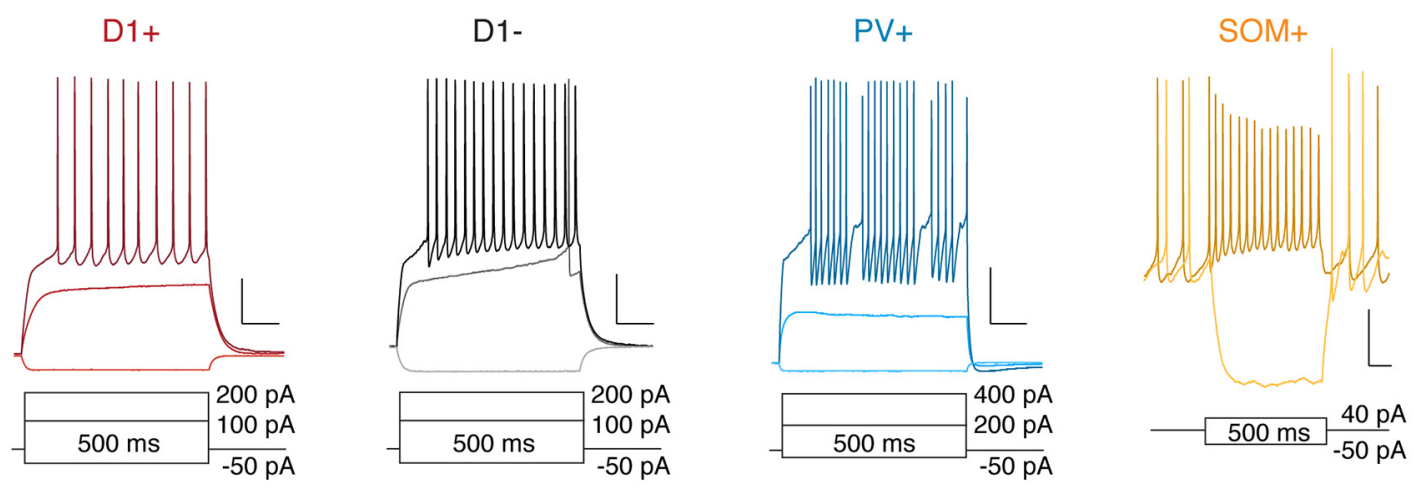

B

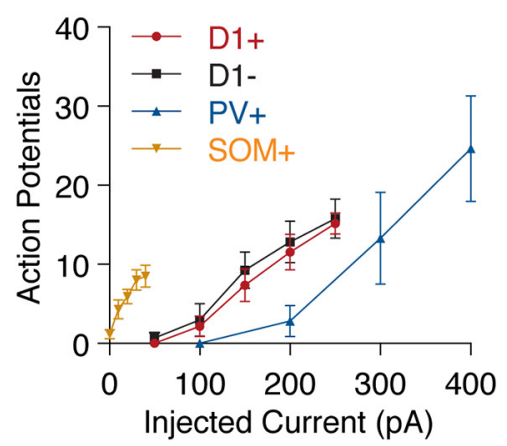

C

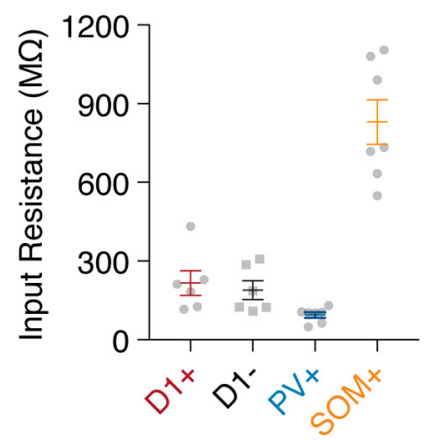

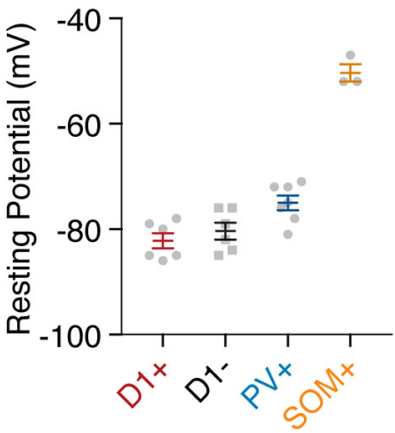

Figure 5. NAccell types display distinct passive and active properties. $A$, Whole-cell current-clamp recordings of D1+ (tdTomato +), D1 - (tdTomato-), PV + (PV-2A-Cre with AAV-DI0-EYFP), and SOM + (SOM-Cre with AAV-DIO-EYFP) cells in the NAc medial shell at resting membrane potentials or in response to current injections. Scale bars $=200 \mathrm{~ms}, 20 \mathrm{mV}$. B, Graph of action potential firing in all cell types during $500 \mathrm{~ms}$ current injections across a range of intensities, with values shown as means \pm SEM. C, Quantification of input resistance (left) and resting membrane potential (right) from all cell types, calculated using a $500 \mathrm{~ms},-50 \mathrm{pA}$ current injection and depicted as means \pm SEM. Note that values for SOM + cells include only cells that were not firing spontaneously.

ing of PV + cells, indicating successful suppression of this population (Fig. 7B; AP probability: activation of ChR2 alone $=1 \pm 0$; ChR2 + ArchT $=0 \pm 0 ; n=6$ cells). Using this approach, we evaluated the effect of suppressing PV + cells on vHPC-evoked EPSCs and feedforward IPSCs in D1+ MSNs. We found that blue light alone evoked robust EPSCs at $-70 \mathrm{mV}$, which were unaffected by the addition of yellow light (Fig. 7C; D1+ EPSCs: $\mathrm{ChR} 2=225 \pm 23 \mathrm{pA} ; \mathrm{ChR} 2+\mathrm{ArchT}=201 \pm 20 \mathrm{pA} ; p=0.078$; $n=7$ cells, 3 mice). Importantly, blue light alone also evoked feedforward IPSCs at $+20 \mathrm{mV}$, and these responses were strongly suppressed by coillumination with yellow light (Fig. 7D; D1+ IPSCs: ChR2 $=200 \pm 20$ pA; ChR $2+\operatorname{ArchT}=67 \pm 9$ pA; $p=$ $0.002 ; n=10$ cells, 3 mice). Together, these results indicate that $\mathrm{PV}+$ interneurons mediate the bulk of vHPC-evoked feedforward inhibition onto MSNs in the NAc medial shell.

\section{Cocaine shifts the excitation/inhibition balance at MSNs}

Repeated exposure to cocaine elicits robust cell-type-specific synaptic plasticity at MSNs in the NAc medial shell (Schmidt and Pierce, 2010; Kim et al., 2011; Volkow and Morales, 2015). The initial bias of vHPC input onto D1+ MSNs is eliminated at a short withdrawal after a $5 \mathrm{~d}$ cocaine sensitization protocol, equalizing excitatory input to the two MSN subtypes (MacAskill et al., 2014). However, if feedforward inhibition of D1 + MSNs also shifts during this experience, it is possible the impact of these changes could be either minimized or exacerbated. Thus, to elucidate the net impact on the activation of these different cell types by vHPC inputs, we next tested how disynaptic inhibition of D1+ and D1- MSNs is impacted by repeated cocaine.
We first confirmed the ability of repeated cocaine to evoke locomotor sensitization, which indicates that synaptic plasticity has occurred (Churchill et al., 1999; Brown et al., 2011; Kim et al., 2011). Following three habituation sessions, mice underwent 5 consecutive days of saline or cocaine administration. After $1 \mathrm{~d}$ withdrawal, a challenge injection of cocaine was given to both saline- and cocaine-treated mice (Fig. 8A). As classically observed, mice receiving cocaine progressively increase their locomotor response throughout sessions compared to their saline-treated counterparts. Moreover, they demonstrated an elevated response to the test injection of cocaine, indicating that robust locomotor sensitization occurred (Fig. $8 B, C$; average velocity: saline-treated $=3.3 \pm 1.1 \mathrm{~cm} / \mathrm{s}$; cocainetreated $=8.9 \pm 0.9 \mathrm{~cm} / \mathrm{s} ; p=0.008 ; n=5$ mice each).

To evaluate the impact of cocaine on NAc circuits, instead of the cocaine challenge after $1 \mathrm{~d}$ of withdrawal, we prepared NAc slices from saline-treated or cocaine-treated mice (Fig. $8 A$ ). Similar to naive mice, vHPC-evoked EPSCs were biased onto D1+ MSNs in the saline condition (EPSCs: D1+ = $252 \pm 35 \mathrm{pA} ; \mathrm{D} 1-=162 \pm 21 \mathrm{pA} ; p=0.003 ; n=11$ pairs, 7 mice). However, this bias was abolished by drug exposure (Fig. $8 D, E$; EPSCs: $\mathrm{D} 1+=218 \pm 35 \mathrm{pA} ; \mathrm{D} 1-=255 \pm 37 \mathrm{pA} ; p=$ $0.38 ; n=13$ pairs, 8 mice). This rebalancing of connectivity resulted in a pronounced shift in the excitation of $\mathrm{D} 1+$ and D1-MSNs (Fig. $8 E$; D1+/D1 - EPSC ratio: saline $=1.5, \mathrm{CI}$ : $1.2-1.9$; cocaine $=0.9$, CI: $0.6-1.3 ; p=0.009 ; n=11$ pairs from 7 mice, 13 pairs from 8 mice).

As in naive mice, we also observed similar feedforward inhibition of D1+ and D1- MSNs in the saline condition (Fig. 8 D, F; IPSCs: D1 $=253 \pm 51$ pA; D1 $-=297 \pm 54$ pA; 
A

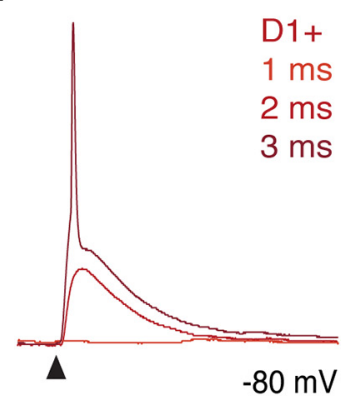

D

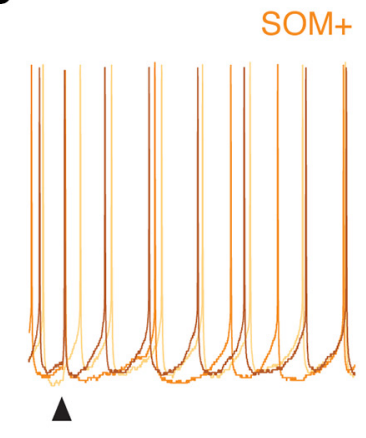

H

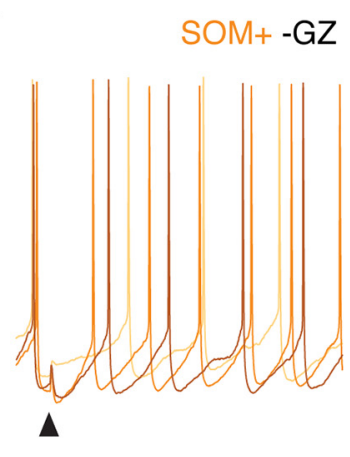

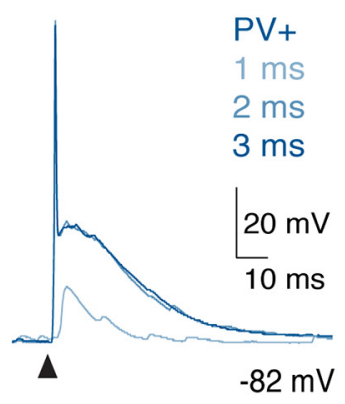

E

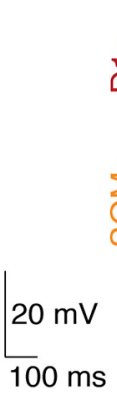

B

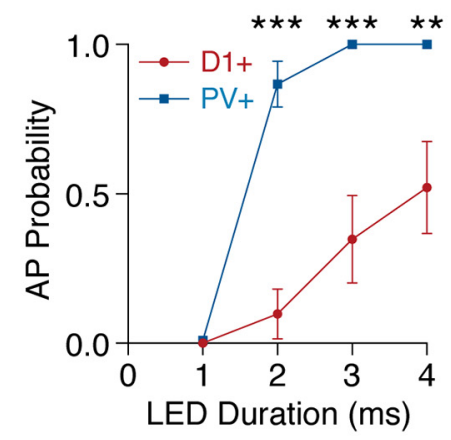

F

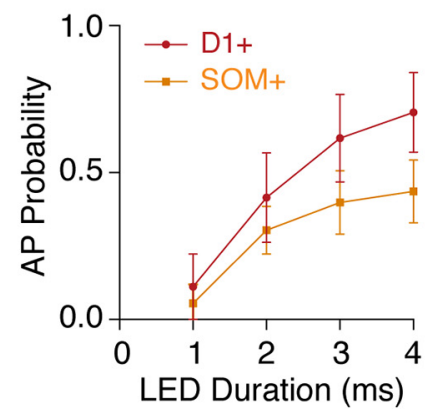

C

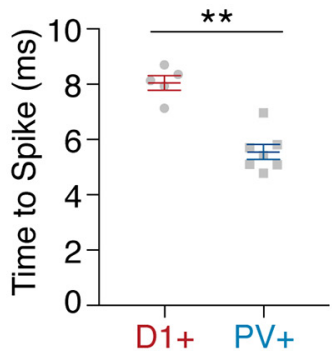

G

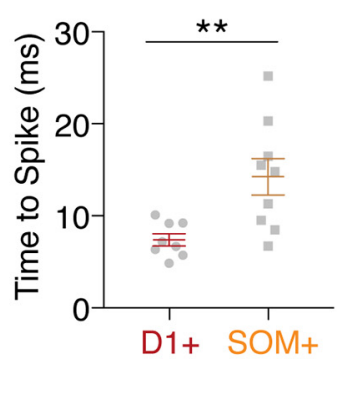

Time (ms)

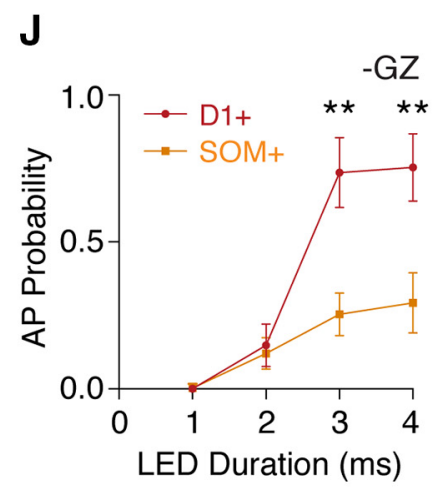

K

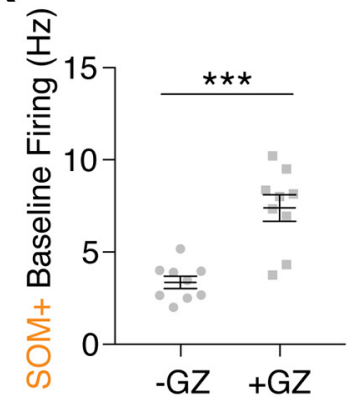

Figure 6. Ventral hippocampal inputs preferentially activate PV + interneurons. $A$, Whole-cell current-clamp recordings of vHPC-evoked EPSPs and spikes in a pair of D1 + and PV + cells from resting membrane potentials, in the presence of CPP, gabazine, and the $G_{A B A}$ R antagonist CGP. Triangles indicate light pulses. $B$, Probability of evoked spiking in D1 + and PV + cells across a range of light durations, shown as means \pm SEM. C, Latency to spike, measured from light onset to peak of AP, for D1+ and PV + cells with 4 ms LED duration. $D$, Similar to $A$ for a spontaneously spiking SOM + interneuron. $\boldsymbol{E}$, Spike raster plot for an example pair of D1 + and SOM + cells, highlighting impact of vHPC inputs (blue line) on spike timing, with the inset showing expanded time around stimulation. $\boldsymbol{F}$, Similar to $\boldsymbol{B}$, showing probability of evoked spiking in D1+ and SOM + cells, calculated during a 10 ms window after light stimulation, with baseline firing rate subtracted. $\mathbf{G}$, Similar to $\boldsymbol{C}$ for $\mathrm{D} 1+$ and SOM + cells. $\boldsymbol{H}-\boldsymbol{J}$, Similar to $\boldsymbol{D}-\boldsymbol{F}$, but in the absence of gabazine to allow for local inhibition. $\boldsymbol{K}$, Baseline firing rate in SOM+ interneurons, with gabazine (+ GZ) or without gabazine $(-\mathrm{GZ})$, shown as means \pm SEM. ${ }^{* *} p<0.01 ;{ }^{* * *} p<0.001$.

$p=0.37 ; n=11$ pairs, 7 mice). However, cocaine exposure did not induce changes in the feedforward inhibition of D1+ and D1- MSNs, despite the large shift in excitatory input (Fig. $8 D, F$; IPSCs: $\mathrm{D} 1+=345 \pm 55 \mathrm{pA} ; \mathrm{D} 1-=422 \pm 88 \mathrm{pA} ; p=$ $0.34 ; n=13$ pairs, 8 mice). Consequently, relative inhibition of the two cell types remained unchanged after cocaine (Fig. $8 F ; \mathrm{D} 1+/ \mathrm{D} 1-\mathrm{IPSC}$ ratio: saline $=0.9, \mathrm{CI}: 0.6-1.2 ;$ cocaine $=$ 1.0, CI: $0.6-1.8 ; p=0.95 ; n=11$ pairs from 7 mice, 13 pairs from 8 mice). Moreover, cocaine altered the excitation/inhibition ratio, which was higher at D1+ MSNs in saline-treated mice (Fig. $8 G$; saline E/I ratio: $\mathrm{D} 1+=1.06$, CI: 0.77-1.45; $\mathrm{D} 1-=0.60$, CI: $0.42-0.86 ; p=0.04 ; n=11$ pairs from 7 mice), but equivalent to D1- MSNs after drug exposure (Fig. $8 G$; cocaine $\mathrm{E} / \mathrm{I}$ ratio: $\mathrm{D} 1+=0.68, \mathrm{CI}: 0.50-0.90 ; \mathrm{D} 1-=$
0.75 , CI: $0.52-1.09 ; p=0.31 ; n=13$ pairs from 8 mice). Together, these results indicate that the effect of cocaine exposure on the excitatory balance of D1+ and D1- MSNs is not accompanied by a shift in the inhibitory balance, suggesting that the relative drive of MSNs by vHPC inputs is indeed altered.

\section{Discussion}

Considerable attention has been paid to how excitatory afferents contact MSNs in the NAc and how this connectivity impacts behavior. Local inhibitory signaling is another critical factor that determines the output of MSNs, but remains much less understood. Here we characterized the feedforward inhibition produced by vHPC afferents to the NAc medial shell. 
A

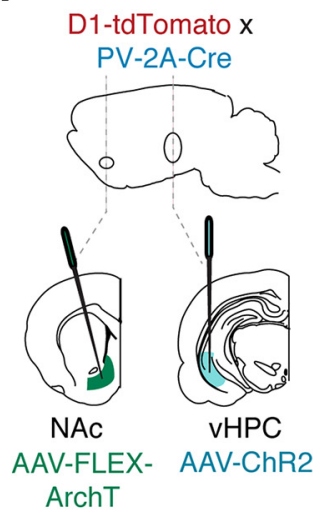

C

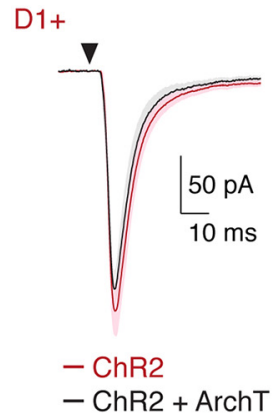

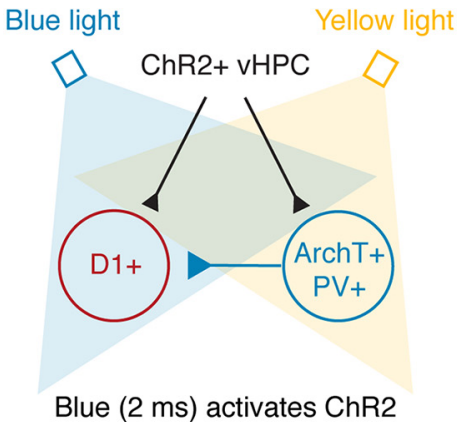

Yellow (350 ms) activates ArchT
B

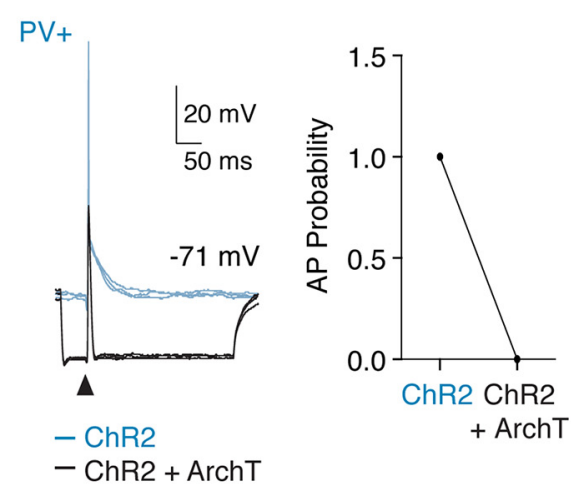

D
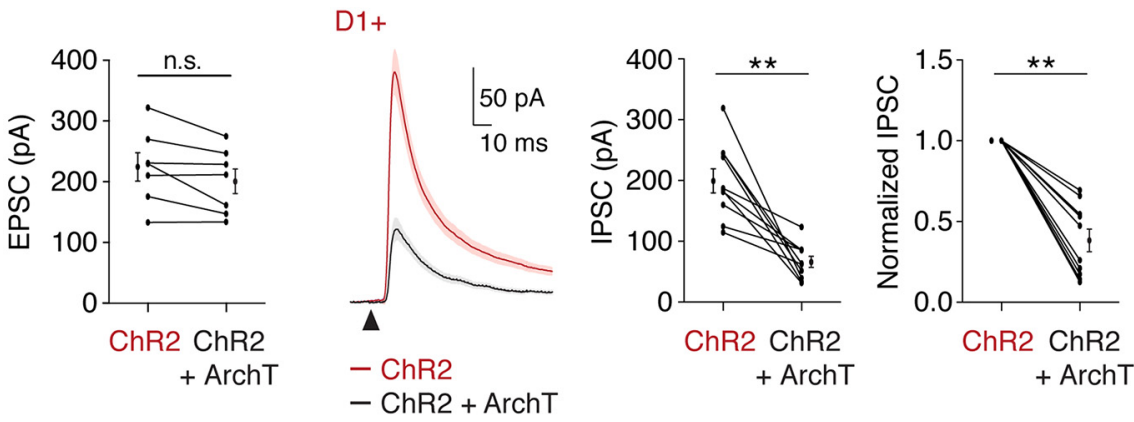

Figure 7. PV + interneurons contribute to feedforward inhibition of MSNs. A, Schematic of experimental design. PV-2A-Cre $\times$ D1-tdTomato mice were coinjected with AAV-CaMKII-ChR2mCherry in the VHPC and AAV-CAG-FLEX-ArchT-GFP in the NAc. In each trial, ChR2 was activated with blue light to trigger vHPC inputs to D1+ MSNs or ArchT+ PV + interneurons. In alternating trials, ArchT was also activated with yellow light to suppress the activity of ArchT+ PV + interneurons. Colored bars indicate timing of ChR2 and ArchT activation. $\boldsymbol{B}$, Current-clamp recording of ArchT + PV + interneurons showing vHPC-evoked spiking by activation of ChR2 (blue trace) that was blocked by simultaneous activation of ArchT (black trace). Right, Quantification of vHPC-evoked spiking, demonstrating effective suppression by ArchT. C, Left, Average vHPC-evoked EPSCs at D1+ MSNs at $-70 \mathrm{mV}$, with (black trace) or without (red trace) suppression of PV + interneurons. Right, Quantification of EPSC amplitude, shown as means \pm SEM, where lines indicate single D1+ MSNs under the two conditions. D, Similar to C for vHPC-evoked IPSCs at $+20 \mathrm{mV}$ in the presence of CPP. Right, Normalized responses, showing reduction in feedforward IPSC s with suppression of PV + interneurons. n.S., Not significant. ${ }^{* *} p<0.01$.

We determined that both $\mathrm{PV}+$ and $\mathrm{SOM}+$ interneurons receive $\mathrm{vHPC}$ input and are capable of providing inhibition to MSN subtypes. However, we found $\mathrm{PV}+$ cells are most strongly activated by these long-range afferents and are primarily responsible for disynaptic inhibition. Moreover, we established that cocaine-evoked plasticity at D1+ MSNs leads to dramatic changes in E/I balance.

Many studies in the cortex highlight balanced E/I ratios at different cell types, achieved through specific targeting of excitatory and inhibitory inputs (Xue et al., 2014; Anastasiades et al., 2018). In contrast, we observed a strong bias of excitation but not inhibition in the NAc, with vHPC inputs preferentially contacting D1+ MSNs, but evoking unbiased feedforward inhibition, yielding unequal E/I ratios in the two MSN subtypes. In the cortex, matching feedforward inhibition to the degree of excitation can equalize the amount of firing a given neuronal population experiences from excitatory input (Isaacson and Scanziani, 2011). The lack of such organization in the NAc suggests that differences in excitatory targeting will result in a substantial difference in evoked spiking, and thus bias output of divergent projection pathways. Because activation of D1+ and D2 + MSNs produces opposite behavioral effects (Lobo et al., 2010), a lack of biased inhibition allows D1+ MSNs to be preferentially activated by vHPC afferents, which could explain why activation of these inputs is able to signal reward (Britt et al., 2012).
Unlike the cortex, the striatum lacks a source of local excitation, and is instead composed almost entirely of MSNs and local interneurons (Gerfen and Bolam, 2010). PV + and SOM + cells are two of the main GABAergic interneurons in the NAc and help regulate local striatal circuits to shape behavior (Tepper et al., 2008; Burke et al., 2017). We found the contributions of the PV+ population could be missed with commonly used $P V$-Cre mice, which works well in the cortex but not in NAc (Hippenmeyer et al., 2005). However, PV + cells can be identified in the NAc of $P V-2 A-C r e$ mice, which may provide more sensitivity to low $\mathrm{PV}$ expression in these cells (Madisen et al., 2010). We established that inhibition evoked by both $\mathrm{PV}+$ and SOM + cells shows no apparent preference for D1+ over D1- MSNs. The absence of bias agrees with recent work using similar optogenetic tools in the dorsal striatum (Straub et al., 2016).

We determined that $\mathrm{vHPC}$ connections are strongest onto $\mathrm{PV}+$ cells, intermediate onto D1+ MSNs, and weakest onto $\mathrm{SOM}+$ cells. While PV + cells have resting potentials and input/output curves similar to those of MSNs, they are strongly and rapidly activated by vHPC inputs. Moreover, their suppression greatly reduces the amplitude of disynaptic IPSCs, suggesting that they are likely the dominant source of feedforward inhibition in the NAc. These findings are reminiscent of cortex, where PV + cells also receive long-range afferents to mediate feedforward inhibition (Swadlow, 2003). They also agree with a previous study in the dorsal striatum that used a similar 
A

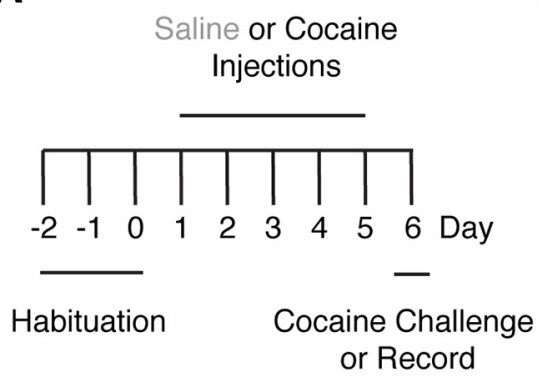

B

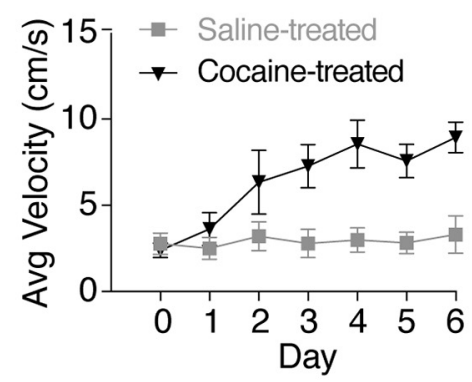

C Saline-treated Cocaine-treated
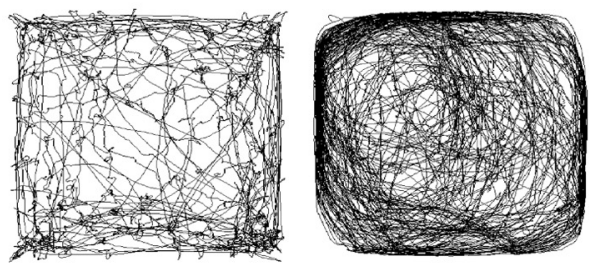

D
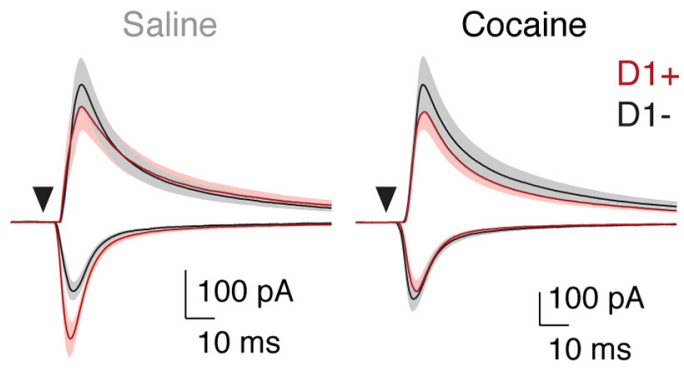

E
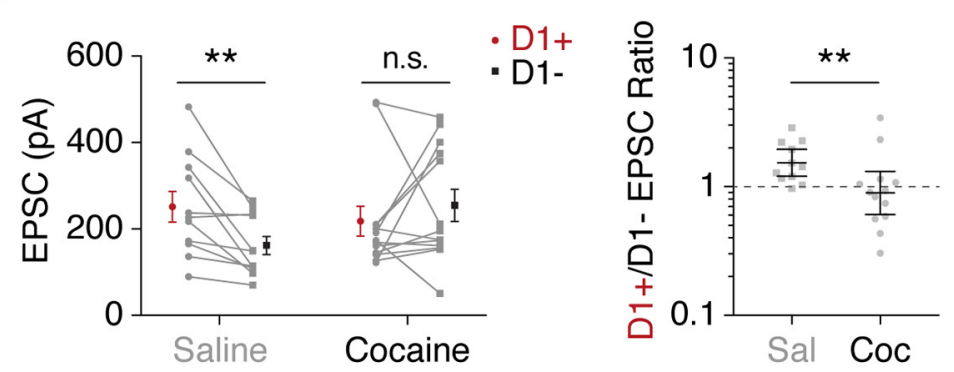

F

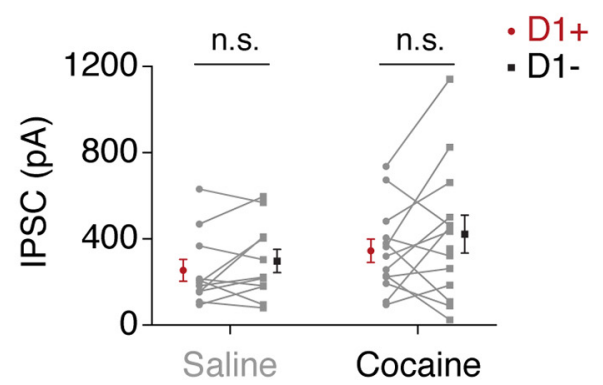

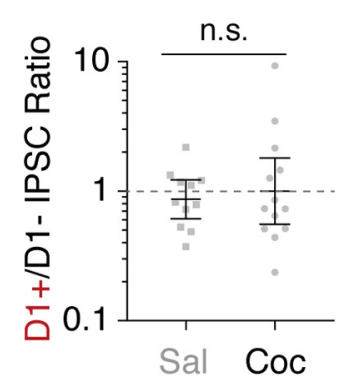

G

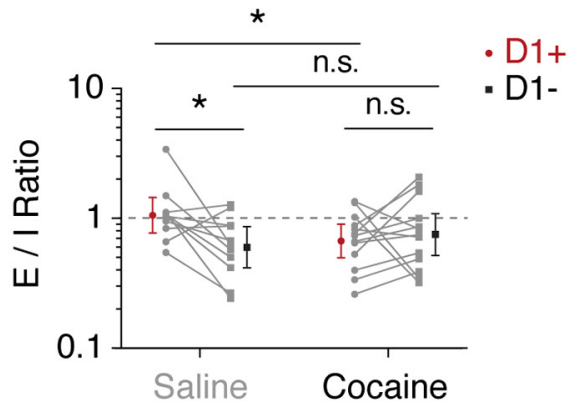

Figure 8. Cocaine exposure alters vHPC-evoked excitation/inhibition balance. $A$, Schematic of cocaine sensitization experiments. Following habituation, animals received daily intraperitoneal injections of cocaine $(15 \mathrm{mg} / \mathrm{kg})$ or saline. After 5 treatment days, animals were either given a cocaine challenge to test for behavioral sensitization or used for in vitro recordings. $\boldsymbol{B}$, Average postinjection locomotion across days for saline- and cocaine-treated animals, depicted as means \pm SEM. C, Example of locomotion after the cocaine challenge on day 6 for cocaine- and saline-treated animals. D, Average vHPC-evoked EPSCs and disynaptic IPSCs in D1 + and D1 - MSNs following saline (left) or cocaine (right) treatment, recorded at -70 or $+20 \mathrm{mV}$ in the presence of CPP. E, Left, Quantification of EPSC amplitudes, indicating a loss of bias after cocaine exposure. Connected data points are pairs of D1 + and D1 - MSNs. Data represent means \pm SEM. Right, Ratio of D1 + to D1 - EPSC amplitudes, shown as geometric means with 95\% confidence intervals. $\boldsymbol{F}$, Similar to $\boldsymbol{E}$ for vHPC-evoked disynaptic IPSCS, showing lack of effect on relative inhibition of D1+ and D1 - MSNs. G, Quantification of the E/I ratio, calculated from vHPC-evoked EPSC and IPSC amplitudes at D1 + and D1- MSNs, shown as geometric means with 95\% confidence intervals. Connected data points represent pairs of neurons. Note the logarithmic axes in $\boldsymbol{E}-\mathbf{G}$. n.S., Not significant. ${ }^{*} p<0.05$; ${ }^{* *} p<0.01$.

optogenetic strategy to identify PV + cells as the primary contributors to cortically evoked disynaptic inhibition onto MSNs and assessed the influence of this inhibition on behavior (Owen et al., 2018). The emerging picture is that PV + cells receive strong excitatory inputs, and mediate feedforward inhibition, signifying that they are likely to be critical regulators of circuits throughout the striatum.

While SOM + cells are a prominent class of GABAergic interneurons, their roles in the local circuit have also been unclear. Interestingly, we find the baseline firing rate and heightened excitability of SOM + cells enable them to respond to weak vHPC input. However, the inability of these cells to rapidly respond to $\mathrm{vHPC}$ inputs makes it unlikely that they mediate feedforward inhibition. Moreover, the slow time course of activation often leaves them susceptible to feedforward inhibition, further preventing rapid spiking. This inhibition could be provided by PV + cells, or other interneurons, such as those expressing tyrosine hydroxylase (Assous et al., 2017) or the 5-HT3A receptor (Muñoz-Manchado et al., 2016). Although we observe little impact on the probability of an evoked spike shortly after stimulation, vHPC and other excitatory inputs could also affect the phase of ongoing spiking and potentially change synchrony of firing across neurons (Isaacson and Scanziani, 2011; Schultheiss et al., 2012). When $\mathrm{SOM}+$ cells are active, it is possible that long-range projections from these cells target dendrites of more distant MSNs (Straub et al., 2016), and could control more distal synapses or gate synaptic plasticity, as observed in pyramidal cells (Isaacson and Scanziani, 2011). The generation of dendritic plateau potentials in MSNs from activation of excitatory inputs is impacted by dendritically targeted inhibition, potentially allowing SOM + synapses to control integration of distal glutamatergic inputs (Du et al., 2017). In addition, SOM + cells could be responsible for providing inhibition onto other cell 
types in the NAc, or may act through different types of GABA receptors. Interestingly, most $\mathrm{SOM}+$ cells in the striatum also express nitric oxide synthase and release nitric oxide, giving them an additional mechanism by which to influence the local circuit (Figueredo-Cardenas et al., 1996; Smith et al., 2017).

While PV + and SOM+ cells are classic GABAergic interneurons, MSNs represent the majority of neurons throughout the striatum. MSNs send GABAergic projections to downstream basal ganglia regions, but can also mediate lateral inhibition within the local circuit (Taverna et al., 2004; Tepper et al., 2008; Dobbs et al., 2016; Burke et al., 2017). In principle, MSNs could also contribute to disynaptic inhibition evoked by long-range inputs, without needing to engage other GABAergic interneurons. However, this is unlikely for two reasons. First, we observe disynaptic inhibition at levels of excitation that are subthreshold for MSN firing. Second, because vHPC inputs are stronger at D1+ than D1- MSNs (MacAskill et al., 2012), and lateral inhibition from D1+ MSNs is biased onto other D1+ MSNs (Taverna et al., 2008), we would expect that vHPC-evoked lateral inhibition would also be biased onto these cells. We instead find this inhibition is similar at D1 + and D1- MSNs, consistent with a primary role for PV + cells, but not MSNs. However, stronger activity will necessarily recruit MSNs, which could ultimately inhibit both MSNs and other cells in the NAc.

Our findings indicate that PV + cells are the primary source of feedforward inhibition evoked by hippocampal afferents. Perturbing these cells, either experimentally or in disease, should have major consequences for behavior. In the cortex, defects in inhibition contribute to epileptic activity and are thought to underlie neuropsychiatric diseases (Yizhar et al., 2011; Marín, 2012). However, it has been less clear how equivalent inhibitory circuits in the striatum support normal function and go awry in disease. Interestingly, patients with Tourette syndrome display a selective decrease in PV + cells in the dorsal striatum (Kalanithi et al., 2005). Previous studies using selective ablation or suppression of PV + cells have observed behavioral effects, including aberrant stereotyped movements and impaired learning (Xu et al. 2016; Lee et al., 2017; Rapanelli et al., 2017; Owen et al., 2018). Similar manipulations of PV + cells in the NAc will also yield valuable information about their role in reward- and addiction-related behaviors, particularly when using the $P V-2 A$-Cre line to access the low PV-expressing cells in the NAc medial shell.

Exposure to cocaine and other drugs of abuse dramatically reorganizes basal ganglia circuitry, particularly at glutamatergic connections within the NAc (Russo et al., 2010; Lüscher and Malenka, 2011; Britt et al., 2012; Pascoli et al., 2011, 2014; Bock et al., 2013; Suska et al., 2013; MacAskill et al., 2014; Sjulson et al., 2018). For example, we previously found in juvenile mice that repeated cocaine shifts the strength of vHPC inputs, reducing their bias onto D1+ MSNs, so they are similar to D2+ MSNs (MacAskill et al., 2014). Here we observed a similar normalization at D1+ and D1- MSNs, indicating that repeated cocaine evokes equivalent plasticity in mature mice. In principle, a similar shift of inhibition would counteract changes in excitation, preserving net activation of D1+ MSNs. However, we observed no equivalent change in the preference of feedforward inhibition onto either D1+ or D1- MSNs. This resulted in a significant drop in the $\mathrm{E} / \mathrm{I}$ ratio at $\mathrm{D} 1+\mathrm{MSN}$, while equalizing the $\mathrm{E} / \mathrm{I}$ ratio at the two cell types, allowing for the effects of drug exposure on glutamatergic inputs to influence output of the NAc.

It is important to note that other glutamatergic afferents may demonstrate different patterns of drug-induced plasticity. For example, repeated cocaine enhances BLA connections onto D1+
MSNs (MacAskill et al., 2014), and BLA inputs to PV+ interneurons show increased presynaptic release probability after cocaine self-administration (Yu et al., 2017). While our results suggest that drug exposure does not induce changes in the relative inhibition of D1+ and D1- MSNs, it is possible that feedforward inhibition of both MSN classes by BLA afferents could be enhanced by cocaine exposure (Yu et al., 2017). Additionally, lateral inhibition between MSNs can be modulated by cocaine to control the overall activity levels of these cells (Dobbs et al., 2016). Interestingly, previous work suggests decreased amplitude of spontaneous inhibitory currents in MSNs at $21 \mathrm{~d}$ of cocaine withdrawal, suggesting that GABAergic connections from interneurons or MSNs may be altered at later time points after drug exposure (Otaka et al., 2013).

Together, our results shed light on the synaptic organization and function of local inhibitory circuits within the NAc, which control the activation of projection neurons via feedforward inhibition. Understanding what sculpts activity patterns of D1+ and D2 + MSNs is vital in assembling a complete picture of basal ganglia circuitry. While this is informative for determining how this circuit supports behavior, our findings also highlight mechanisms by which exposure to drugs of abuse rewires the NAc. Such changes alter the relative drive of these two populations and thus inhibition of downstream areas, and contribute to the development of drug-seeking behaviors. Future studies will need to determine the in vivo activity patterns of these sparse interneuron populations and how the widespread inhibitory control provided by these cells impacts behavior.

\section{References}

Ade KK, Wan Y, Chen M, Gloss B, Calakos N (2011) An improved BAC transgenic fluorescent reporter line for sensitive and specific identification of striatonigral medium spiny neurons. Front Syst Neurosci 5:32. Medline

Anastasiades PG, Marlin JJ, Carter AG (2018) Cell-type specificity of callosally evoked excitation and feedforward inhibition in the prefrontal cortex. Cell Rep 22:679-692. CrossRef Medline

Assous M, Kaminer J, Shah F, Garg A, Koós T, Tepper JM (2017) Differential processing of thalamic information via distinct striatal interneuron circuits. Nat Commun 8:15860. CrossRef Medline

Barrientos C, Knowland D, Wu MMJ, Lilascharoen V, Huang KW, Malenka RC, Lim BK (2018) Cocaine-induced structural plasticity in input regions to distinct cell types in nucleus accumbens. Biol Psychiatry. Advance online publication. Retrieved August, 24, 2018. doi:10.1016/j.biopsych. 2018.04.019. Medline

Beatty JA, Sullivan MA, Morikawa H, Wilson CJ (2012) Complex autonomous firing patterns of striatal low-threshold spike interneurons. J Neurophysiol 108:771-781. CrossRef Medline

Bock R, Shin JH, Kaplan AR, Dobi A, Markey E, Kramer PF, Gremel CM, Christensen CH, Adrover MF, Alvarez VA (2013) Strengthening the accumbal indirect pathway promotes resilience to compulsive cocaine use. Nat Neurosci 16:632-638. CrossRef Medline

Britt JP, Benaliouad F, McDevitt RA, Stuber GD, Wise RA, Bonci A (2012) Synaptic and behavioral profile of multiple glutamatergic inputs to the nucleus accumbens. Neuron 76:790-803. CrossRef Medline

Brown TE, Lee BR, Mu P, Ferguson D, Dietz D, Ohnishi YN, Lin Y, Suska A, Ishikawa M, Huang YH, Shen H, Kalivas PW, Sorg BA, Zukin RS, Nestler EJ, Dong Y, Schlüter OM (2011) A silent synapse-based mechanism for cocaine-induced locomotor sensitization. J Neurosci 31:8163-8174. CrossRef Medline

Burke DA, Rotstein HG, Alvarez VA (2017) Striatal local circuitry: a new framework for lateral inhibition. Neuron 96:267-284. CrossRef Medline

Calipari ES, Bagot RC, Purushothaman I, Davidson TJ, Yorgason JT, Peña CJ, Walker DM, Pirpinias ST, Guise KG, Ramakrishnan C, Deisseroth K, Nestler EJ (2016) In vivo imaging identifies temporal signature of D1 and D2 medium spiny neurons in cocaine reward. Proc Natl Acad Sci U S A 113:2726-2731. CrossRef Medline

Carter AG, Sabatini BL (2004) State-dependent calcium signaling in den- 
dritic spines of striatal medium spiny neurons. Neuron 44:483-493. CrossRef Medline

Cepeda C, André VM, Yamazaki I, Wu N, Kleiman-Weiner M, Levine MS (2008) Differential electrophysiological properties of dopamine D1 and D2 receptor-containing striatal medium-sized spiny neurons. Eur J Neurosci 27:671-682. CrossRef Medline

Chalifoux JR, Carter AG (2010) GABAB receptors modulate NMDA receptor calcium signals in dendritic spines. Neuron 66:101-113. CrossRef Medline

Choi K, Holly EN, Davatolhagh MF, Beier KT, Fuccillo MV (2018) Integrated anatomical and physiological mapping of striatal afferent projections. Eur J Neurosci. Advance online publication. Retrieved August 24, 2018. doi:10.1111/ejn.13829.

Churchill L, Swanson CJ, Urbina M, Kalivas PW (1999) Repeated cocaine alters glutamate receptor subunit levels in the nucleus accumbens and ventral tegmental area of rats that develop behavioral sensitization. J Neurochem 72:2397-2403. Medline

Dobbs LK, Kaplan AR, Lemos JC, Matsui A, Rubinstein M, Alvarez VA (2016) Dopamine regulation of lateral inhibition between striatal neurons gates the stimulant actions of cocaine. Neuron 90:1100-1113. CrossRef Medline

Doig NM, Moss J, Bolam JP (2010) Cortical and thalamic innervation of direct and indirect pathway medium-sized spiny neurons in mouse striatum. J Neurosci 30:14610-14618. CrossRef Medline

Du K, Wu YW, Lindroos R, Liu Y, Rózsa B, Katona G, Ding JB, Kotaleski JH (2017) Cell-type-specific inhibition of the dendritic plateau potential in striatal spiny projection neurons. Proc Natl Acad Sci U S A 114:E7612E7621. CrossRef Medline

Figueredo-Cardenas G, Morello M, Sancesario G, Bernardi G, Reiner A (1996) Colocalization of somatostatin, neuropeptide $Y$, neuronal nitric oxide synthase and NADPH-diaphorase in striatal interneurons in rats. Brain Res 735:317-324. CrossRef Medline

Finch DM (1996) Neurophysiology of converging synaptic inputs from the rat prefrontal cortex, amygdala, midline thalamus, and hippocampal formation onto single neurons of the caudate/putamen and nucleus accumbens. Hippocampus 6:495-512. CrossRef Medline

Gerfen CR, Bolam JP (2010) The neuroanatomical organization of the basal ganglia. Handb Behav Neurosci 20:3-28. CrossRef

Gerfen CR, Surmeier DJ (2011) Modulation of striatal projection systems by dopamine. Annu Rev Neurosci 34:441-466. CrossRef Medline

Gerfen CR, Engber TM, Mahan LC, Susel Z, Chase TN, Monsma FJ Jr, Sibley DR (1990) D1 and D2 dopamine receptor-regulated gene expression of striatonigral and striatopallidal neurons. Science 250: 1429-1432. CrossRef Medline

Gertler TS, Chan CS, Surmeier DJ (2008) Dichotomous anatomical properties of adult striatal medium spiny neurons. J Neurosci 28:1081410824. CrossRef Medline

Gittis AH, Nelson AB, Thwin MT, Palop JJ, Kreitzer AC (2010) Distinct roles of GABAergic interneurons in the regulation of striatal output pathways. J Neurosci 30:2223-2234. CrossRef Medline

Gittis AH, Hang GB, LaDow ES, Shoenfeld LR, Atallah BV, Finkbeiner S, Kreitzer AC (2011) Rapid target-specific remodeling of fast-spiking inhibitory circuits after loss of dopamine. Neuron 71:858-868. CrossRef Medline

Gong S, Zheng C, Doughty ML, Losos K, Didkovsky N, Schambra UB, Nowak NJ, Joyner A, Leblanc G, Hatten ME, Heintz N (2003) A gene expression atlas of the central nervous system based on bacterial artificial chromosomes. Nature 425:917-925.

Hikida T, Kimura K, Wada N, Funabiki K, Nakanishi S (2010) Distinct roles of synaptic transmission in direct and indirect striatal pathways to reward and aversive behavior. Neuron 66:896-907. CrossRef Medline

Hippenmeyer S, Vrieseling E, Sigrist M, Portmann T, Laengle C, Ladle DR, Arber S (2005) A developmental switch in the response of DRG neurons to ETS transcription factor signaling. PLoS Biol 3:e159. CrossRef Medline

Hu H, Gan J, Jonas P (2014) Fast-spiking, parvalbumin + GABAergic interneurons: from cellular design to microcircuit function. Science 345: 1255263. CrossRef Medline

Humphries MD, Prescott TJ (2010) The ventral basal ganglia, a selection mechanism at the crossroads of space, strategy, and reward. Prog Neurobiol 90:385-417. CrossRef Medline

Isaacson JS, Scanziani M (2011) How inhibition shapes cortical activity. Neuron 72:231-243. CrossRef Medline
Kalanithi PS, Zheng W, Kataoka Y, DiFiglia M, Grantz H, Saper CB, Schwartz ML, Leckman JF, Vaccarino FM (2005) Altered parvalbumin-positive neuron distribution in basal ganglia of individuals with Tourette syndrome. Proc Natl Acad Sci U S A 102:13307-13312. CrossRef Medline

Kawaguchi Y (1993) Physiological, morphological, and histochemical characterization of three classes of interneurons in rat neostriatum. J Neurosci 13:4908-4923. CrossRef Medline

Kawaguchi Y, Wilson CJ, Augood SJ, Emson PC (1995) Striatal interneurones: chemical, physiological and morphological characterization. Trends Neurosci 18:527-535. CrossRef Medline

Kim J, Park BH, Lee JH, Park SK, Kim JH (2011) Cell type-specific alterations in the nucleus accumbens by repeated exposures to cocaine. Biol Psychiatry 69:1026-1034. CrossRef Medline

Kreitzer AC (2009) Physiology and pharmacology of striatal neurons. Annu Rev Neurosci 32:127-147. CrossRef Medline

Lee K, Holley SM, Shobe JL, Chong NC, Cepeda C, Levine MS, Masmanidis SC (2017) Parvalbumin interneurons modulate striatal output and enhance performance during associative learning. Neuron 93:1451-1463. CrossRef Medline

Lei W, Jiao Y, Del Mar N, Reiner A (2004) Evidence for differential cortical input to direct pathway versus indirect pathway striatal projection neurons in rats. J Neurosci 24:8289-8299. CrossRef Medline

Little JP, Carter AG (2012) Subcellular synaptic connectivity of layer 2 pyramidal neurons in the medial prefrontal cortex. J Neurosci 32:1280812819. CrossRef Medline

Lobo MK, Nestler EJ (2011) The striatal balancing act in drug addiction: distinct roles of direct and indirect pathway medium spiny neurons. Front Neuroanat 5:41. Medline

Lobo MK, Covington HE 3rd, Chaudhury D, Friedman AK, Sun H, DamezWerno D, Dietz DM, Zaman S, Koo JW, Kennedy PJ, Mouzon E, Mogri M, Neve RL, Deisseroth K, Han MH, Nestler EJ (2010) Cell type-specific loss of BDNF signaling mimics optogenetic control of cocaine reward. Science 330:385-390. CrossRef Medline

Lüscher C, Malenka RC (2011) Drug-evoked synaptic plasticity in addiction: from molecular changes to circuit remodeling. Neuron 69:650663. CrossRef Medline

MacAskill AF, Little JP, Cassel JM, Carter AG (2012) Subcellular connectivity underlies pathway-specific signaling in the nucleus accumbens. Nat Neurosci 15:1624-1626. CrossRef Medline

MacAskill AF, Cassel JM, Carter AG (2014) Cocaine exposure reorganizes cell type- and input-specific connectivity in the nucleus accumbens. Nat Neurosci 17:1198-1207. CrossRef Medline

Madisen L, Zwingman TA, Sunkin SM, Oh SW, Zariwala HA, Gu H, Ng LL, Palmiter RD, Hawrylycz MJ, Jones AR, Lein ES, Zeng H (2010) A robust and high-throughput cre reporting and characterization system for the whole mouse brain. Nat Neurosci 13:133-140. CrossRef Medline

Mahn M, Prigge M, Ron S, Levy R, Yizhar O (2016) Biophysical constraints of optogenetic inhibition at presynaptic terminals. Nat Neurosci 19:554556. CrossRef Medline

Mallet N, Le Moine C, Charpier S, Gonon F (2005) Feedforward inhibition of projection neurons by fast-spiking GABA interneurons in the rat striatum in vivo. J Neurosci 25:3857-3869. CrossRef Medline

Marín O (2012) Interneuron dysfunction in psychiatric disorders. Nat Rev Neurosci 13:107-120. CrossRef Medline

Moore AK, Weible AP, Balmer TS, Trussell LO, Wehr M (2018) Rapid rebalancing of excitation and inhibition by cortical circuitry. Neuron 97: 1341-1355. CrossRef Medline

Muñoz-Manchado AB, Foldi C, Szydlowski S, Sjulson L, Farries M, Wilson C, Silberberg G, Hjerling-Leffler J (2016) Novel striatal GABAergic interneuron populations labeled in the 5HT3a EGFP mouse. Cereb Cortex 26:96-105. CrossRef Medline

O’Donnell P, Grace AA (1995) Synaptic interactions among excitatory afferents to nucleus accumbens neurons: hippocampal gating of prefrontal cortical input. J Neurosci 15:3622-3639. CrossRef Medline

Otaka M, Ishikawa M, Lee BR, Liu L, Neumann PA, Cui R, Huang YH, Schlüter OM, Dong Y (2013) Exposure to cocaine regulates inhibitory synaptic transmission in the nucleus accumbens. J Neurosci 33:67536758. CrossRef Medline

Owen SF, Berke JD, Kreitzer AC (2018) Fast-spiking interneurons supply feedforward control of bursting, calcium, and plasticity for efficient learning. Cell 172:683-695. CrossRef Medline

Pascoli V, Turiault M, Lüscher C (2011) Reversal of cocaine-evoked synap- 
tic potentiation resets drug-induced adaptive behaviour. Nature 481:7175. CrossRef Medline

Pascoli V, Terrier J, Espallergues J, Valjent E, O’Connor EC, Lüscher C (2014) Contrasting forms of cocaine-evoked plasticity control components of relapse. Nature 509:459-464. CrossRef Medline

Pennartz CM, Kitai ST (1991) Hippocampal inputs to identified neurons in an in vitro slice preparation of the rat nucleus accumbens: evidence for feed-forward inhibition. J Neurosci 11:2838-2847. CrossRef Medline

Planert H, Szydlowski SN, Hjorth JJ, Grillner S, Silberberg G (2010) Dynamics of synaptic transmission between fast-spiking interneurons and striatal projection neurons of the direct and indirect pathways. J Neurosci 30:3499-3507. CrossRef Medline

Plotkin JL, Wu N, Chesselet MF, Levine MS (2005) Functional and molecular development of striatal fast-spiking GABAergic interneurons and their cortical inputs. Eur J Neurosci 22:1097-1108. CrossRef Medline

Ramanathan S, Hanley JJ, Deniau JM, Bolam JP (2002) Synaptic convergence of motor and somatosensory cortical afferents onto GABAergic interneurons in the rat striatum. J Neurosci 22:8158-8169. CrossRef Medline

Rapanelli M, Frick LR, Xu M, Groman SM, Jindachomthong K, Tamamaki N, Tanahira C, Taylor JR, Pittenger C (2017) Targeted interneuron depletion in the dorsal striatum produces autism-like behavioral abnormalities in male but not female mice. Biol Psychiatry 82:194-203. CrossRef Medline

Robinson TE, Kolb B (2004) Structural plasticity associated with exposure to drugs of abuse. Neuropharmacology 47:33-46. CrossRef Medline

Rudkin TM, Sadikot AF (1999) Thalamic input to parvalbumin-immunoreactive GABAergic interneurons: organization in normal striatum and effect of neonatal decortication. Neuroscience 88:1165-1175. CrossRef Medline

Russo SJ, Dietz DM, Dumitriu D, Morrison JH, Malenka RC, Nestler EJ (2010) The addicted synapse: mechanisms of synaptic and structural plasticity in nucleus accumbens. Trends Neurosci 33:267-276. CrossRef Medline

Schmidt HD, Pierce RC (2010) Cocaine-induced neuroadaptations in glutamate transmission. Ann N Y Acad Sci 1187:35-75. CrossRef

Schultheiss NW, Prinz AA, Butera RJ (2012) Phase response curves in neuroscience. New York, NY: Springer Science+Business Media.

Sesack SR, Grace AA (2010) Cortico-basal ganglia reward network: microcircuitry. Neuropsychopharmacology 35:27-47. CrossRef Medline

Silberberg G, Markram H (2007) Disynaptic inhibition between neocortical pyramidal cells mediated by Martinotti cells. Neuron 53:735-746. CrossRef Medline

Sjulson L, Peyrache A, Cumpelik A, Cassataro D, Buzsáki G (2018) Cocaine place conditioning strengthens location-specific hippocampal coupling to the nucleus accumbens. Neuron 98:926-934. CrossRef Medline

Smith AC, Scofield MD, Heinsbroek JA, Gipson CD, Neuhofer D, RobertsWolfe DJ, Spencer S, Garcia-Keller C, Stankeviciute NM, Smith RJ, Allen NP, Lorang MR, Griffin WC 3rd, Boger HA, Kalivas PW (2017) Accumbens nNOS interneurons regulate cocaine relapse. J Neurosci 37:742-756. CrossRef Medline

Smith RJ, Lobo MK, Spencer S, Kalivas PW (2013) Cocaine-induced adaptations in D1 and D2 accumbens projection neurons (a dichotomy not necessarily synonymous with direct and indirect pathways). Curr Opin Neurobiol 23:546-552. CrossRef Medline
Straub C, Saulnier JL, Bègue A, Feng DD, Huang KW, Sabatini BL (2016) Principles of synaptic organization of GABAergic interneurons in the striatum. Neuron 92:84-92. CrossRef Medline

Suska A, Lee BR, Huang YH, Dong Y, Schlüter OM (2013) Selective presynaptic enhancement of the prefrontal cortex to nucleus accumbens pathway by cocaine. Proc Natl Acad Sci U S A 110:713-718. CrossRef Medline

Swadlow HA (2003) Fast-spike interneurons and feedforward inhibition in awake sensory neocortex. Cereb Cortex 13:25-32. CrossRef Medline

Taniguchi H, He M, Wu P, Kim S, Paik R, Sugino K, Kvitsani D, Fu Y, Lu J, Lin Y, Miyoshi G, Shima Y, Fishell G, Nelson SB, Huang ZJ, Huang ZJ (2011) A resource of cre driver lines for genetic targeting of GABAergic neurons in cerebral cortex. Neuron 71:995-1013. CrossRef Medline

Taverna S, van Dongen YC, Groenewegen HJ, Pennartz CM (2004) Direct physiological evidence for synaptic connectivity between medium-sized spiny neurons in rat nucleus accumbens in situ. J Neurophysiol 91:11111121. CrossRef Medline

Taverna S, Canciani B, Pennartz CM (2007) Membrane properties and synaptic connectivity of fast-spiking interneurons in rat ventral striatum. Brain Res 1152:49-56. CrossRef Medline

Taverna S, Ilijic E, Surmeier DJ (2008) Recurrent collateral connections of striatal medium spiny neurons are disrupted in models of Parkinson's disease. J Neurosci 28:5504-5512. CrossRef Medline

Tepper JM, Bolam JP (2004) Functional diversity and specificity of neostriatal interneurons. Curr Opin Neurobiol 14:685-692. CrossRef Medline

Tepper JM, Wilson CJ, Koós T (2008) Feedforward and feedback inhibition in neostriatal GABAergic spiny neurons. Brain Res Rev 58:272-281. CrossRef Medline

Volkow ND, Morales M (2015) The brain on drugs: from reward to addiction. Cell 162:712-725. CrossRef Medline

Wall NR, De La Parra M, Callaway EM, Kreitzer AC (2013) Differential innervation of direct- and indirect-pathway striatal projection neurons. Neuron 79:347-360. CrossRef Medline

Wong AC, Shetreat ME, Clarke JO, Rayport S (1999) D1- and D2-like dopamine receptors are co-localized on the presynaptic varicosities of striatal and nucleus accumbens neurons in vitro. Neuroscience 89:221-233. CrossRef Medline

Xu M, Li L, Pittenger C (2016) Ablation of fast-spiking interneurons in the dorsal striatum, recapitulating abnormalities seen post-mortem in Tourette syndrome, produces anxiety and elevated grooming. Neuroscience 324:321-329. CrossRef Medline

Xue M, Atallah BV, Scanziani M (2014) Equalizing excitation-inhibition ratios across visual cortical neurons. Nature 511:596-600. CrossRef Medline

Yizhar O, Fenno LE, Prigge M, Schneider F, Davidson TJ, O’Shea DJ, Sohal VS, Goshen I, Finkelstein J, Paz JT, Stehfest K, Fudim R, Ramakrishnan C, Huguenard JR, Hegemann P, Deisseroth K (2011) Neocortical excitation/inhibition balance in information processing and social dysfunction. Nature 477:171-178. CrossRef Medline

Yu J, Yan Y, Li KL, Wang Y, Huang YH, Urban NN, Nestler EJ, Schlüter OM, Dong Y (2017) Nucleus accumbens feedforward inhibition circuit promotes cocaine self-administration. Proc Natl Acad Sci U S A 114:E8750 E8759. CrossRef Medline 